\title{
Movements, dispersion, and mixing of bigeye tuna (Thunnus obesus) tagged and released in the equatorial Central Pacific Ocean, with conventional and archival tags
}

\author{
Kurt Schaefer $^{\mathrm{a}, *}$, Daniel Fuller ${ }^{\mathrm{a}}$, John Hampton ${ }^{\mathrm{b}}$, Sylvain Caillot ${ }^{\mathrm{b}}$, \\ Bruno Leroy ${ }^{\mathrm{b}}$, David Itano ${ }^{\mathrm{b}}$ \\ a Inter-American Tropical Tuna Commission, La Jolla, CA, United States \\ ${ }^{\mathrm{b}}$ Secretariat of the Pacific Community, Oceanic Fisheries Programme, Noumea, New Caledonia
}

\section{A R T I C L E I N F O}

\section{Article history:}

Received 4 June 2014

Received in revised form 29 August 2014

Accepted 30 August 2014

Handling Editor A.E. Punt

\section{Keywords:}

Bigeye tuna

Equatorial Pacific

Plastic dart and archival tags

Horizontal movements

Dispersion

\begin{abstract}
A B S T R A C T
A total of 31,242 bigeye tuna was captured, tagged, and released, 30,793 with dart tags (DTs) and 449 with geolocating archival tags (ATs), in the equatorial central Pacific Ocean along the $140^{\circ} \mathrm{W}, 155^{\circ} \mathrm{W}, 170^{\circ} \mathrm{W}$, and $180^{\circ}$ meridians, during 2008 through 2012, of which 10,029 (32.1\%) of the DTs and 74 (16.5\%) of the ATs were returned. A subset of high-confidence filtered DT data was retained for 5807 fish at liberty for $30 \mathrm{~d}$ or more, for evaluating linear displacements from release to recapture positions. For the filtered DT data, days at liberty ranged from 30 to $1701 \mathrm{~d}$ (median=187 d). Linear displacements ranged from 1 to 5372 nautical miles $(\mathrm{M})$ ( median = $936 \mathrm{M}$ ), with 71\% eastward and 29\% westward, and 95\% within $3614 \mathrm{M}$ of their release positions. The data indicate significant differences in the linear displacements by release locations, days at liberty, and fish length at release. An unscented Kalman filter model with sea-surface temperature measurements integrated (UKFsst) was used to process 48 AT data sets from bigeye tuna at liberty for $30 \mathrm{~d}$ or longer, to obtain most probable tracks, improved estimates of geographic positions, and movement parameters. The $95 \%$ volume contours surrounding the position estimates, along the most probable tracks from bigeye tuna releases along the $140^{\circ} \mathrm{W}, 155^{\circ} \mathrm{W}, 170^{\circ} \mathrm{W}$, and $180^{\circ}$ meridians show substantial overlap. For the pooled AT data sets, the median parameter estimates from the UKFsst model for errors in longitude $\left(\sigma_{x}\right)$ and latitude $\left(\sigma_{y}\right)$ were $0.52^{\circ}$ and $1.75^{\circ}$, for directed eastward and northward movements ( $u$ and $v$ ) were $-2.01 \mathrm{M} / \mathrm{d}$ and $-1.41 \mathrm{M} / \mathrm{d}$, and for dispersive movement $(D)$ was $496.7 \mathrm{M}^{2} / \mathrm{d}$. The linear displacements and most probable tracks obtained from these tagging data demonstrate constrained latitudinal dispersion, some regional fidelity, some extensive eastward longitudinal dispersion, and substantial mixing of bigeye tuna between release longitudes. The amount of mixing of bigeye tuna among these release areas in the equatorial central Pacific Ocean, with those in adjacent areas of the equatorial eastern and western Pacific Ocean, is dependent on distances between areas, with, in general, the greatest mixing occurring between the areas that are closest to one another.
\end{abstract}

(c) 2014 Elsevier B.V. All rights reserved.

\section{Introduction}

Bigeye tuna (Thunnus obesus) inhabit tropical to temperate oceanic waters of the Pacific Ocean, from about $40^{\circ} \mathrm{N}$ to $40^{\circ} \mathrm{S}$. Since the 1950s they have been a primary target of Japanese large-scale longline fisheries (Miyabe and Bayliff, 1998; Miyake et al., 2004). The predominant catches of bigeye tuna across the Pacific Ocean by longline vessels, during 2008-2012, were from about $15^{\circ} \mathrm{N}$ to $15^{\circ}$ S (Fig. 1). During the 1990s, large-scale tropical tuna purse-seine

\footnotetext{
* Corresponding author. Tel.: +1 8585467159.

E-mail address: kschaefer@iattc.org (K. Schaefer).
}

fisheries, in the eastern and western Pacific began targeting mixedspecies tuna aggregations, dominated by skipjack tuna (Katsuwonus pelamis), associated with drifting fish-aggregating devices (DFADS) (Fonteneau et al., 2000, 2013). This mode of purse-seine fishing has escalated over the past two decades, including geographical expansion of fishing effort, resulting in a large incidental annual catch of small bigeye tuna, caught primarily between $5^{\circ} \mathrm{N}$ and $5^{\circ}$ S across the equatorial Pacific (Fig. 1) (Anonymous, 2013; Williams and Terawasi, 2013).

The targeting of mixed-species tuna aggregations associated with DFADs by purse-seine vessels across the equatorial Pacific has resulted in dramatic increases in the fishing mortality of smaller, younger bigeye tuna, which has lowered the maximum sustainable 


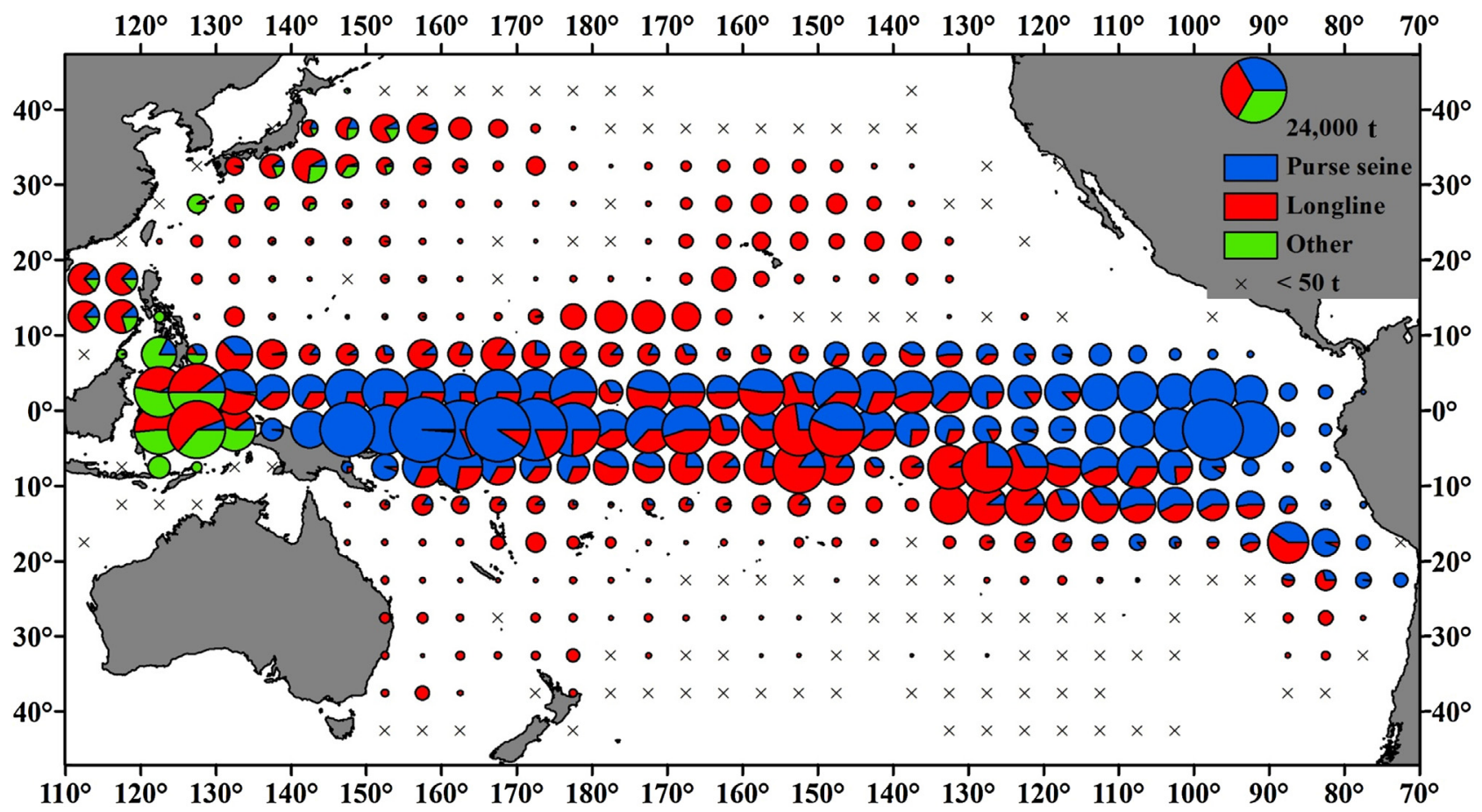

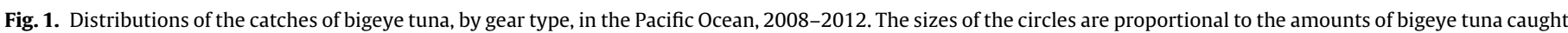
in those $5^{\circ}$ by $5^{\circ}$ areas.

yield of stocks. The recent stock assessment for bigeye tuna in the western and central Pacific Ocean (WCPO) (west of $150^{\circ} \mathrm{W}$ ) (Davies et al., 2011) indicated that overfishing is occurring, but the stock is not in an overfished state. In contrast, the recent stock assessment for bigeye tuna in the eastern Pacific Ocean (EPO) (east of $150^{\circ} \mathrm{W}$ ) (Aires-da-Silva and Maunder, 2014) indicated that overfishing is not occurring, the stock is in an overfished state, but that there is substantial uncertainty in the estimates. There are several critical assumptions in both assessments, about which the results are highly sensitive, including the stock structure of bigeye tuna across the Pacific Ocean, and the amount of mixing among regions (Hoyle et al., 2013).

Information on the movement patterns and population structure of any species of fish is necessary for stock assessments and management. Tag release and recapture experiments, utilizing conventional plastic dart tags (DTs), conducted for tropical tunas in various areas of the world, have provided valuable information on movements and population structure, for over 60 years (Hunter et al., 1986; Bayliff, 1993). In recent years, tagging experiments utilizing electronic geolocating archival tags (ATs), have provided unparalleled information on movements, dispersion, mixing, and population structure of temperate and tropical tunas (Block et al., 2005; Boustany et al., 2010; Schaefer et al., 2011).

Movements of bigeye tuna inferred from tagging experiments utilizing DTs in the Coral Sea (Hampton and Gunn, 1998), Hawaii (Itano and Holland, 2000), Japan (Matsumoto et al., 2007) and the equatorial WCPO (Hampton and Williams, 2005) and EPO (Schaefer and Fuller, 2009) indicate that, although there are some longerdistance linear displacements (LDs), $90 \%$ or more are restricted to within about 1000 nautical miles (M) of their release locations, even after substantial periods of time at liberty. The movements and dispersion for bigeye tuna released with ATs in the Coral Sea (Clear et al., 2005) and equatorial EPO (Schaefer and Fuller, 2009, 2010) indicated that the area utilized was restricted primarily to within $1000 \mathrm{M}$ of the release locations, but some fish moved far greater distances, and some exhibited seasonal cyclical migrations. Results from those bigeye tuna tagging studies with DTs and ATs, conducted in sub-tropical and equatorial areas of the Pacific, showed relatively restricted movements and regional fidelity. We define regional fidelity as fish tagged with DTs being recaptured within $1000 \mathrm{M}$ of their release locations, or when the most probable tracks (MPTs) from fish tagged with ATs indicate they remained within $1000 \mathrm{M}$, or exhibited cyclical excursions outside that range but returned to within $1000 \mathrm{M}$.

Bigeye tuna release locations in previous tagging experiments in the equatorial western Pacific Ocean (WPO) and EPO were at great distances from the $150^{\circ} \mathrm{W}$ meridian, and thus only low levels of dispersion across that fluid boundary, between the convention areas of the Inter-American Tropical Tuna Commission (IATTC) and the Western and Central Pacific Fisheries Commission (WCPFC) (Anonymous, 2011), would be expected. The results of those studies provided some insights into bigeye tuna movement patterns and dispersion, and indicated mixing of bigeye tuna should perhaps be expected within and between overlapping areas defined by $1000 \mathrm{M}$ radii across the equatorial Pacific.

The objectives of this investigation are to describe the horizontal movements and dispersion of bigeye tuna tagged and released with DTs and ATs during 2008-2012, in the equatorial central Pacific Ocean (CPO), and to estimate the amount of mixing with fish in adjacent areas. LDs based on high-confidence filtered DT recapture data, along with the MPTs and movement parameters, derived from AT data sets, are the basis of this investigation. The results obtained have direct implications for consideration of stock structure and mixing rates used in stock assessments, and resource management applications, for bigeye tuna in the Pacific Ocean.

\section{Materials and methods}

\subsection{Tag releases}

Bigeye tuna found in association with the National Oceanic and Atmospheric Administration (NOAA) Tropical Atmosphere Ocean (TAO) moorings, on the $140^{\circ} \mathrm{W}, 155^{\circ} \mathrm{W}, 170^{\circ} \mathrm{W}$, and $180^{\circ} \mathrm{TAO}$ arrays, between $8^{\circ} \mathrm{N}$ and $8^{\circ} \mathrm{S}$, were captured, tagged, and released 
between May and June, and/or September to December, from 2008 to 2012. Tagging was conducted during eight cruises, five originating from Hawaii with tagging activities along the $140^{\circ} \mathrm{W}, 155^{\circ}$ $\mathrm{W}$, and $170^{\circ} \mathrm{W}$ meridians, and three originating from Tonga with tagging activities along the $170^{\circ} \mathrm{W}$ and $180^{\circ}$ meridians. Tagging cruises originating from Hawaii were on the chartered commercial tuna fishing vessel FV Double D during 2008 and 2009, the FV Ao Shibi Go during 2009, 2010, and 2011, and those originating from Tonga on the FV Pacific Sunrise during 2010, 2011, and 2012.

The fishing vessels were fitted with galvanized steel davits, on their port and/or starboard sides, to enable the use of Hawaiianstyle dangler gear during the day. The davits were designed to extend at right angles from the hull for about $2 \mathrm{~m}$, and about headhigh from the deck. They were rigged with shackles from which two very short handlines are suspended for trolling on the surface, slightly behind the davits. Handline gear was also rigged from the stern of these vessels for trolling on the surface, during the day, from distances of a few meters to about $20 \mathrm{~m}$ behind the vessel. Plastic squids with barbless hooks were used on the dangler and stern trolling lines. During the night, the fishing was done from a drifting vessel using handlines, hydraulic reels, and an assortment of standup-style sportfishing rods and reels. The terminal tackle used at night was a variety of heavy metal jigs, mostly chrome or chrome/glow, rigged with barbless hooks.

Fish with obvious damage to the gills or eyes, or exhibiting severe bleeding, were rejected for tagging.

During most of the tagging cruises, before departing from a TAO mooring where a substantial number of tunas had been tagged and released, attempts were made to entice the tuna aggregation away in association with the tagging vessel, to prevent the aggregation from being captured by a purse-seine vessel that might set on fish associated with the mooring soon after release. This maneuver was successfully done following most tagging events, by keeping the vessel in close proximity to the TAO mooring at night with all the high intensity deck lights on, and a few hours before dawn drifting away with the aggregation associated with the vessel. After establishing, at a distance of a few $M$ from a TAO mooring, that an aggregation was associated with the tagging vessel, the drift would normally continue for $24 \mathrm{~h}$ or more so as to be about $20 \mathrm{M}$ or further away, before getting underway and disassociating the aggregation from the vessel. A sea anchor was commonly used to increase the speed of the drift by reducing the potentially negative impact of the wind relative to current direction, and to increase the attraction of the aggregation. Attempts were also frequently made to tag bigeye tuna while drifting with the aggregation during the day and night, including in the morning, by dropping the sea anchor with a float and trolling around it.

\subsection{Dart tags}

Fish were tagged with one serially numbered $13-\mathrm{cm}$ yellow DT manufactured by Hallprint Pty, Ltd., Hindmarsh Valley, South Australia, using tubular stainless steel applicators. Tags were inserted, on one side of the fish, into the dorsal musculature with the barbed heads passing between the pterygiophores below the base of the second dorsal fin. A request that the finder report the recapture of the fish and informing him or her that there was a reward for the return of the tag was printed on these tags. Most fish less than about $1 \mathrm{~m}$ in length were measured and tagged in cradles, with $1-\mathrm{cm}$ graduations marked on a smooth vinyl liner. There were two or three tagging stations, each with a cradle, set up on the fishing deck of each vessel for optimal efficiency. Methods similar to those used in this study for tagging tunas with DTs are described by Bayliff and Holland (1986). Fish larger than about $1 \mathrm{~m}$ in length, captured primarily at night using handline or sportfishing gear,
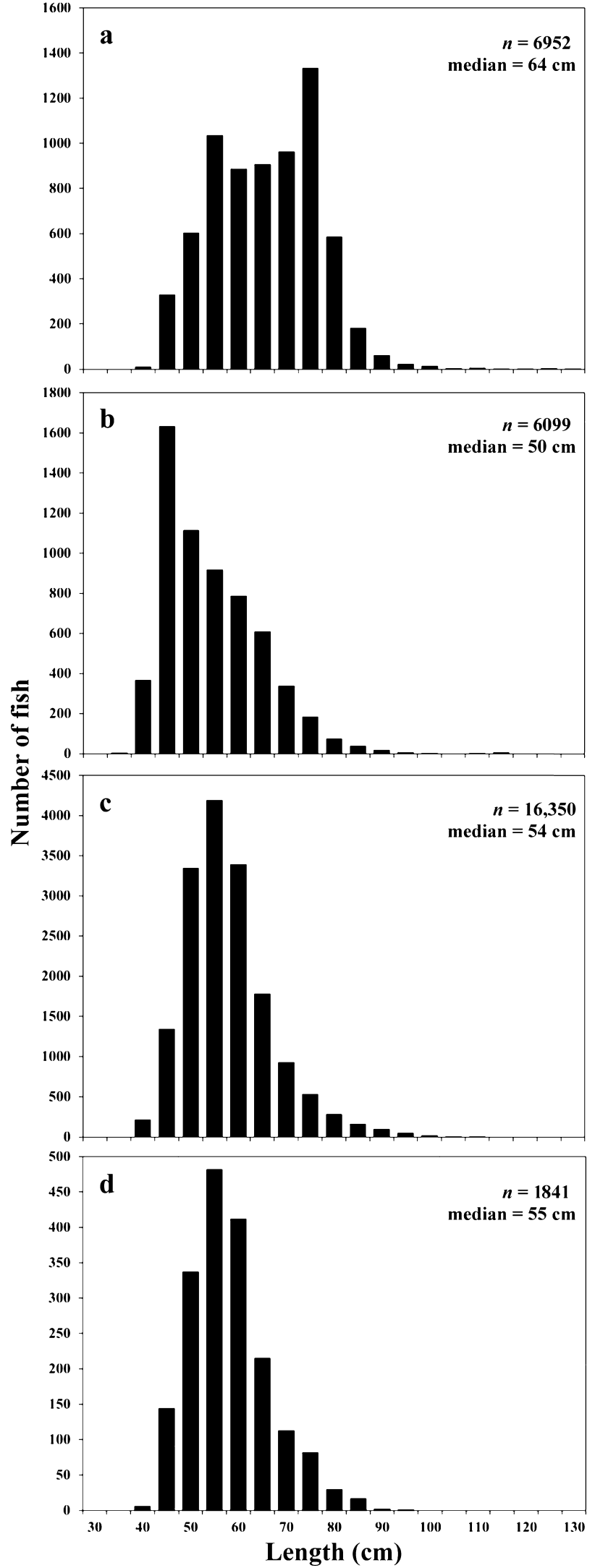

Fig. 2. Length-frequency distributions of bigeye tuna released with plastic dart tags at (a) $140^{\circ} \mathrm{W}$, (b) $155^{\circ} \mathrm{W}$, (c) $170^{\circ} \mathrm{W}$, and (d) $180^{\circ}$. 
were landed with heavy-duty long-handled aluminum-frame nets (75-cm inside diameter), hung with knotless webbing, onto a mat of high-density foam with a smooth vinyl cover. Those fish were measured to the nearest $1 \mathrm{~mm}$ with a caliper. Tag release information, including date and time, fishing location, fishing gear type, tagging station, species, length, and tag type(s) were recorded, using digital voice recorders in waterproof pouches suspended around the necks of taggers. Following tagging events, the release data recorded were transcribed to paper forms aboard the vessel, usually within $24 \mathrm{~h}$ of a tagging event.

An extensive international publicity campaign intended to inform captains and crews of purse-seine and longline vessels, cannery managers and workers, unloaders of purse-seine vessels, and observers monitoring longline vessel transhipments about the tagging project and subsequent rewards for the return of tags was established through the Pacific Tuna Tagging Program (Leroy et al., 2013) well in advance of this project. The reward for the return of each DT was US\$10, or US\$15 beginning in late 2011 in Manta, Ecuador, when fish with tags intact were presented by finders to the tag recovery officer (TRO) the same day recovered, along with reliable information on the vessel and well in which the tagged fish was found. In addition, drawings were held under various scenarios for awarding prizes up to US\$500 each. Each tag returned entitled the finder one chance to win the drawing.

\subsection{Archival tags}

The ATs deployed were model Mk9, manufactured by Wildlife Computers, Redmond, WA, USA, and the LTD2310 and LAT2810 manufactured by Lotek Wireless, Inc., St. John's, Newfoundland, Canada. These tag configurations are designed for internal implantation into the coelom of fish. The external sensor stalk from which the ambient light-level and temperature measurements originate exits the body of the fish through an incision. A label with information about reporting the recovery of the tag and the associated reward (US\$250) was encased in the main body of the instruments. The depth (pressure), ambient and internal temperatures, and light-level data were programmed to be stored in the memory of the tags at frequencies of either 30 or $60 \mathrm{~s}$. The materials and methods used for tagging and releasing bigeye tuna with archival tags are described by Schaefer and Fuller (2002).

\subsection{Tag recoveries}

Most recoveries of DTs and ATs were made during the unloading of purse-seine vessels or transshipment vessels while in port, but there were also some recoveries aboard purse-seine and longline vessels at sea. The primary recapture information sought is the recapture date and location, vessel name and type, and the length of the fish. However, most of the tags are recovered by unloaders of purse-seine vessels, and transshipment vessels, and the information commonly provided is the date the tagged fish was found, along with the vessel name and the number of the storage well in which it was found. Comparing that information with observer records from purse-seine trips in the EPO, and vessel log sheets and/or vessel monitoring system (VMS) data for purse-seine trips in the WCPO, it is normally possible to verify with reasonable accuracy the recapture dates and locations for most tagged fish recovered during the unloading of purse-seine vessels. However, for tagged fish recovered from transshipment vessels, where the fish from all wells of the purse-seine vessel are consolidated, the level of accuracy of the recapture information is far less, since it is equivalent to the range in dates and locations of all sets during the fishing trip.
In cases for which a field office technician working in collaboration with the IATTC or WCPFC received a fish with the tag intact from a finder during the unloading of a purse-seine vessel and the storage well number confirmed, or an observer aboard a purseseine vessel during a trip was shown a recaptured tagged fish following a set, the recapture information was classified as high confidence. Recaptures by longline vessels were usually found at sea and accurate recapture details provided. Such recaptures were also classified as high confidence.

\subsection{Data processing}

A computer program designed for entering and accessing all tagging data, along with associated information and analysis, was created by staff of the Oceanic Fisheries Programme of the Secretariat of the Pacific Community, for the Pacific Tuna Tagging Programme (PTTP).

The summary statistics for all bigeye tuna tagged and released with DTs and ATs during the equatorial CPO cruises of 2008-2012, and the subsequent recapture information for all tag recoveries through the end of June 2014 are presented in this study.

\subsubsection{Dart tags}

A subset of the DT data was selected for describing movements, and included only tagging data for fish that were at liberty for $30 \mathrm{~d}$ or more. All tags for which the recapture information was classified as high confidence, and most all of the tags for which the recovery information (date found, vessel name, and well number) was confirmed to correspond to a set made by that vessel during a trip within a 5-degree area were included. All tags recovered from transshipment vessels, which accounted for $15.2 \%$ of the total DT returns, were excluded. For the DT recoveries included in the subset of data, if the purse-seine well from which the tagged fish was recovered contained fish from more than one set, the recapture date and location for the tagged fish was assigned to the set that had the greatest amount of bigeye tuna in that well. As an additional precautionary step in the selection of the subset of data, the DT data that were not classified as high confidence were filtered to eliminate any tag recoveries for which the linear displacement velocities exceeded the maximum velocities of the high-confidence data within the following four categories of days at liberty (DAL): 30-89 (26.1 M/d), 90-179 (23.2 M/d), 180-365 $(19.3 \mathrm{M} / \mathrm{d})$, and $>365(11.7 \mathrm{M} / \mathrm{d})$. This resulted in eliminating the following numbers and percentages of recoveries from each of those categories, respectively: 66 (5.9\%), 26 (1.5\%), 18 (0.8\%), and 2 $(0.2 \%)$.

Queries were written to extract release and recapture information from the DT subset data file in required formats for use in other software packages. Pearson correlation analysis was used to test for relationships between LDs and DAL, and fish length at release (Zar, 1974). Null hypotheses were rejected at a confidence level of $95 \%$ (5\% significance level).

\subsubsection{Archival tags}

Data were downloaded from the recovered tags, using software provided by the tag manufacturers.

AT recapture date is determined directly from the time series data downloaded from the tag. Utilizing the date of recapture and the vessel name provided by the finder. Recapture position is determined from an abstract of the vessel logbook, observer records, and/or VMS data.

Position estimates provided from the tag manufacturer's proprietary software were based on ambient light-level data, with times of dawn and dusk used to estimate longitude from the time of local noon, and latitude from the local day length (Ekstrom, 
Table 1

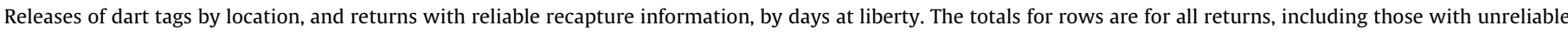
recapture information.

\begin{tabular}{|c|c|c|c|c|c|c|c|c|}
\hline \multirow[t]{2}{*}{ Area } & \multirow[t]{2}{*}{ Released } & \multicolumn{7}{|c|}{ Returned } \\
\hline & & $<30$ & $30-89$ & $90-179$ & 180-365 & $>365$ & Reliable (\%) & Total (\%) \\
\hline $2^{\circ} \mathrm{S} 140^{\circ} \mathrm{W}$ & 694 & 2 & 64 & 130 & 38 & 11 & $245(35.3)$ & $318(45.8)$ \\
\hline $0^{\circ} 140^{\circ} \mathrm{W}$ & 4079 & 6 & 50 & 310 & 750 & 145 & 1261 (30.9) & $1440(35.3)$ \\
\hline $2^{\circ} \mathrm{N} 140^{\circ} \mathrm{W}$ & 2178 & 80 & 106 & 182 & 198 & 87 & $653(30.0)$ & $829(38.1)$ \\
\hline $5^{\circ} \mathrm{N} 140^{\circ} \mathrm{W}$ & 1 & 0 & 0 & 0 & 0 & 1 & $1(100.0)$ & $1(100.0)$ \\
\hline $0^{\circ} 155^{\circ} \mathrm{W}$ & 3941 & 79 & 124 & 231 & 221 & 101 & $756(19.2)$ & $1099(27.9)$ \\
\hline $2^{\circ} \mathrm{N} 155^{\circ} \mathrm{W}$ & 1285 & 3 & 117 & 88 & 63 & 49 & $320(24.9)$ & $445(34.6)$ \\
\hline $5^{\circ} \mathrm{N} 155^{\circ} \mathrm{W}$ & 456 & 2 & 25 & 35 & 16 & 13 & $91(20.0)$ & $131(28.7)$ \\
\hline $8^{\circ} \mathrm{N} 155^{\circ} \mathrm{W}$ & 417 & 1 & 8 & 11 & 26 & 10 & $56(13.4)$ & $81(19.4)$ \\
\hline $2^{\circ} \mathrm{S} 170^{\circ} \mathrm{W}$ & 4457 & 979 & 111 & 139 & 157 & 97 & $1483(33.3)$ & $1981(44.4)$ \\
\hline $0^{\circ} 170^{\circ} \mathrm{W}$ & 7068 & 9 & 247 & 372 & 374 & 174 & $1176(16.6)$ & $2044(28.9)$ \\
\hline $2^{\circ} \mathrm{N} 170^{\circ} \mathrm{W}$ & 4818 & 96 & 155 & 135 & 254 & 147 & $787(16.3)$ & $1196(24.8)$ \\
\hline $5^{\circ} \mathrm{N} 170^{\circ} \mathrm{W}$ & 7 & 0 & 0 & 0 & 0 & 0 & $0(0.0)$ & $0(0.0)$ \\
\hline $5^{\circ} \mathrm{S} 180^{\circ}$ & 1 & 0 & 0 & 0 & 0 & 0 & $0(0.0)$ & $0(0.0)$ \\
\hline $2^{\circ} \mathrm{S} 180^{\circ}$ & 329 & 1 & 18 & 24 & 3 & 8 & $54(16.4)$ & $118(35.9)$ \\
\hline $0^{\circ} 180^{\circ}$ & 955 & 0 & 15 & 36 & 23 & 10 & $84(8.8)$ & $186(19.5)$ \\
\hline $2^{\circ} \mathrm{N} 180^{\circ}$ & 556 & 0 & 7 & 21 & 40 & 30 & $98(17.6)$ & $160(28.8)$ \\
\hline All & 31,242 & 1258 & 1047 & 1714 & 2163 & 883 & $7065(22.6)$ & $10,029(32.1)$ \\
\hline
\end{tabular}

2004). The raw light-based latitude estimates were highly variable and unreliable around the time of the equinoxes due to the nearly constant day length at all latitudes. Daily SST values derived from the archival tag data were calculated with algorithms provided by the tag manufacturers.

Daily sea-surface temperatures (SSTs) recorded by the tags matched to SSTs from remote sensing have been shown to significantly improve estimates of latitude (Teo et al., 2004; Nielsen et al., 2006).

The unscented Kalman filter with SST measurements integrated (UKFsst) (Lam et al., 2008), was used to obtain improved estimates of positions, MPTs, and movement parameters. The UKFsst model (Nielsen et al., 2006) a state-space model in which the transition equation describes the movements, is very similar to the Kalman filter, with SST measurements integrated. The UKFsst is a better model for handling non-linearities, and also has the advantage that every model parameter is handled within a statistical framework. The UKFsst can also utilize remotely sensed SST data of various spatial resolutions, and it automatically estimates the amount of smoothing required for the SST field. The UKFsst parameterizes movement as a biased random walk, with the movement partitioned into directed ( $u$ and $v$ ) and dispersive $(D)$ movements. The model also estimates the geolocation errors as the longitude $\left(\sigma_{x}\right)$ and latitude $\left(\sigma_{y}\right)$ standard deviations.

The NCEP Reynolds Optimally Interpolated 8-d SST composite product with $1^{\circ}$ area resolution (accuracy of $0.5-0.7^{\circ} \mathrm{C}$ ), derived from Advanced Very High Resolution Radiometer (AVHRR) Pathfinder data and in situ measurements of SST (Reynolds and Smith, 1994), was utilized in the UKFsst model.

For the 48 fish at liberty for 30 or more days, a daily position was estimated along the MPTs, except when no position was available due to the lack of a light-based position estimate, or tag failure. The number of estimated positions as a percentage of the deployment period for each fish ranged from $40 \%$ to $100 \%$. For the 48 fish, a total of 6687 estimated daily positions (81\%), were obtained from the 8255 total number of days, for which tags functioned.

Each set of position estimates along the MPT for individual bigeye tuna, derived from the UKFsst model, was integrated into a Geographic Information System (GIS). The ArcView GIS program was used for spatial analyses of the data sets. The $95 \%$ volume contours, from a kernel density function for all positions included with a $1^{\circ}$ search radius and a $0.01^{\circ}$ output cell size, were calculated, using ArcGis v.10, for each release area.

\section{Results}

\subsection{Releases and recoveries of dart tags}

The numbers of releases of DTs by location, returns with reliable recapture information by DAL, and total returns, are given in Table 1 . The percentages of total returns, for the releases along the $140^{\circ} \mathrm{W}, 155^{\circ} \mathrm{W}, 170^{\circ} \mathrm{W}$, and $180^{\circ}$ meridians, are all fairly similar except for the fish released at the TAO buoy moored at $2^{\circ} \mathrm{S} 170^{\circ}$ $\mathrm{W}$. There were 929 fish recaptured in a single set by a purse-seine vessel, after 10-12 DAL, which were associated with the same TAO mooring where they were released.

The percentages of recaptures by DAL for all returns, with reliable recapture information, show an interesting pattern with $30.6 \%$ at $180-365 \mathrm{~d}$, being greater than for fish at liberty for $<30 \mathrm{~d}(17.8 \%)$, $30-89 \mathrm{~d}$ (14.8\%), 90-179 d (24.2\%), and >365 d (12.5\%).

For the 31,242 releases, 10,029 bigeye tuna have been recaptured and their tags returned as of 30 June $2014 ; 9239(92.1 \%)$ by purse-seine vessels, $60(0.60 \%)$ by trolling vessels, $33(0.33 \%)$ by longline vessels, $13(0.05 \%)$ by hand-line vessels, $1(0.01 \%)$ by gillnet, $1(0.01 \%)$ by pole-and-line, $1(0.01 \%)$ by hook-and-line, and 681 (6.8\%) were unclassified.

\subsubsection{Length distributions of releases by area}

The median length for bigeye tunas released with DTs was greatest for releases along the $140^{\circ} \mathrm{W}$ meridian (Fig. 2), due to the greater proportion of fish larger than about $65 \mathrm{~cm}$. The length-frequency distributions and median lengths for releases along the $155^{\circ} \mathrm{W}$, $170^{\circ} \mathrm{W}$, and $180^{\circ}$ meridians were all fairly similar.

\subsection{Days at liberty and linear displacements}

\subsubsection{Releases at the $140^{\circ} \mathrm{W}$ meridian}

For 2072 fish $\geq 30$ DAL, released along the $140^{\circ} \mathrm{W}$ meridian, the median DAL was $201 \mathrm{~d}$ (range: 30-1054 d) and the median LD was $1326 \mathrm{M}$ (range: $7-3870 \mathrm{M}$ ). $95 \%$ were recaptured within $2737 \mathrm{M}$ of the release position, and $76 \%$ exhibited eastward displacements $\left(0-180^{\circ}\right)$ (Table 2$)$. The fish with the greatest DAL (1054 d) was recaptured by a purse-seine vessel $694 \mathrm{M}$ and at a bearing of $132^{\circ}$ from the release position. The fish with the greatest LD $(3870 \mathrm{M})$ was also recaptured by a purse-seine vessel, at a bearing of $110^{\circ}$ from the release position after 509 DAL. The distribution of recaptures by 1-degree areas ranges from the most easterly position of $17^{\circ} 26^{\prime} \mathrm{S} 77^{\circ} 33^{\prime} \mathrm{W}$ to the most westerly position of $1^{\circ} 52^{\prime} \mathrm{S} 170^{\circ} 35^{\prime}$ 
Table 2

Bigeye tuna linear displacements by release longitude, and days at liberty. Eastward linear displacements are defined as those from $0^{\circ}$ to $180^{\circ}$ of release location.

\begin{tabular}{|c|c|c|c|c|c|c|}
\hline \multirow[t]{2}{*}{ Release longitude } & \multirow[t]{2}{*}{ Days at liberty } & \multirow[t]{2}{*}{$n$} & \multicolumn{4}{|c|}{ Linear displacement (M) } \\
\hline & & & Median & $95 \%$ & Range & \% Eastward \\
\hline \multirow{5}{*}{$140^{\circ} \mathrm{W}$} & $30-89$ & 220 & 248 & 999 & $67-2158$ & 64 \\
\hline & $90-179$ & 622 & 859 & 2681 & $7-2841$ & 62 \\
\hline & $180-365$ & 986 & 1748 & 2679 & $20-3334$ & 89 \\
\hline & $>365$ & 244 & 1971 & 2805 & $116-3870$ & 91 \\
\hline & All & 2072 & 1326 & 2702 & $7-3870$ & 76 \\
\hline \multirow{5}{*}{$155^{\circ} \mathrm{W}$} & $30-89$ & 274 & 390 & 1114 & $54-1971$ & 56 \\
\hline & $90-179$ & 365 & 612 & 1680 & $24-2962$ & 70 \\
\hline & $180-365$ & 326 & 898 & 2698 & $48-3431$ & 78 \\
\hline & $>365$ & 173 & 1276 & 3586 & $127-4694$ & 80 \\
\hline & All & 1138 & 668 & 2660 & $24-4694$ & 71 \\
\hline \multirow{5}{*}{$170^{\circ} \mathrm{W}$} & $30-89$ & 513 & 355 & 1120 & $10-2068$ & 52 \\
\hline & $90-179$ & 646 & 756 & 1556 & $1-4012$ & 43 \\
\hline & $180-365$ & 785 & 1546 & 3733 & $62-5104$ & 83 \\
\hline & $>365$ & 418 & 3217 & 4648 & $58-5372$ & 89 \\
\hline & All & 2362 & 951 & 4331 & $1-5372$ & 66 \\
\hline \multirow{5}{*}{$180^{\circ}$} & $30-89$ & 40 & 529 & 1499 & $97-1767$ & 40 \\
\hline & $90-179$ & 81 & 348 & 1741 & $48-3427$ & 33 \\
\hline & $180-365$ & 66 & 1941 & 3977 & $112-5136$ & 94 \\
\hline & $>365$ & 48 & 4135 & 5199 & $402-5240$ & 94 \\
\hline & All & 235 & 933 & 4876 & $48-5240$ & 64 \\
\hline All & & 5807 & 936 & 3614 & $1-5372$ & 71 \\
\hline
\end{tabular}
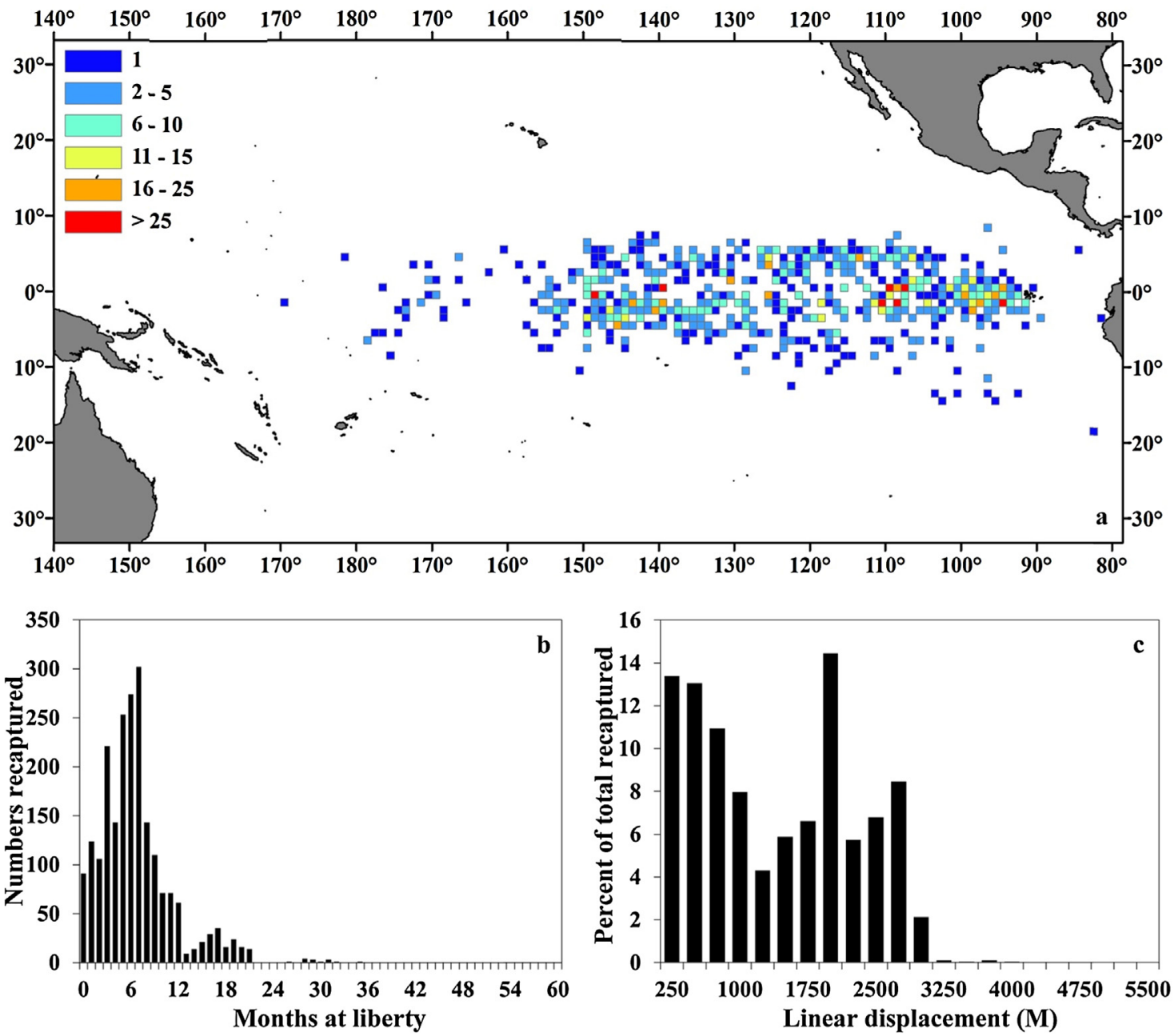

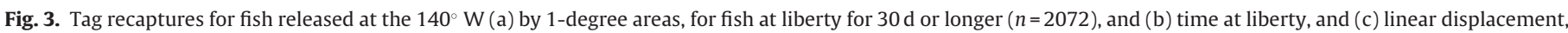
for all recaptures $(n=2160)$. 

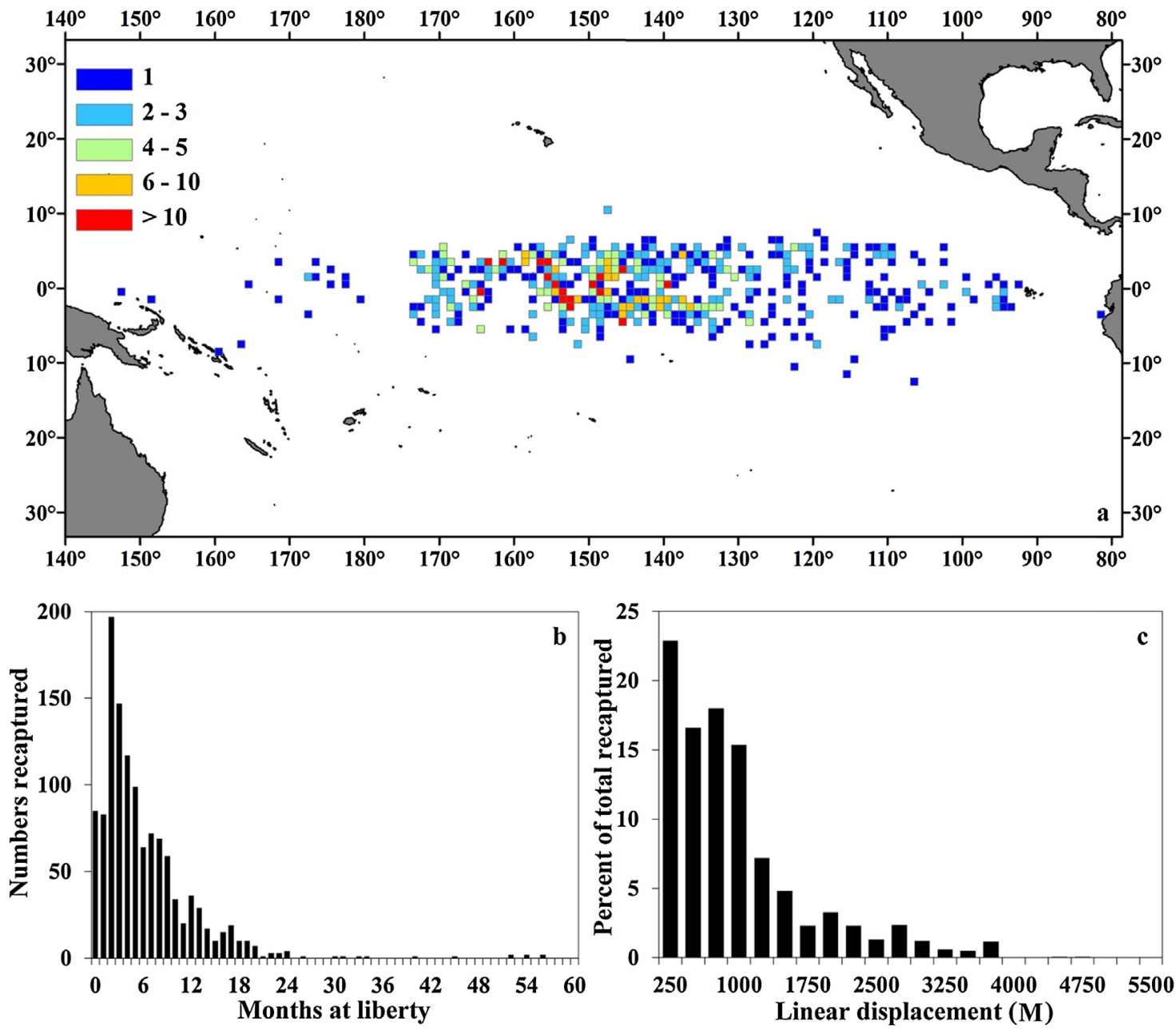

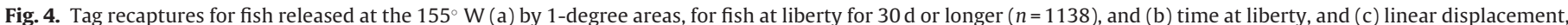
for all recaptures $(n=1223)$.

$\mathrm{E}$, and from the most northerly position of $11^{\circ} 25^{\prime} \mathrm{N} 124^{\circ} 33^{\prime} \mathrm{W}$ to the most southerly position of $18^{\circ} 25^{\prime} \mathrm{S} 82^{\circ} 54^{\prime} \mathrm{W}$ (Fig. 3). There is a significant positive correlation between the LDs for the 2072 bigeye tuna and DAL $(r=0.309, P<0.0001)$, which is also evident with the increasing LD statistics, relative to greater DAL categories (Table 2). Although there is only a small range in length with 1934 (94\%) between 40 and $80 \mathrm{~cm}$, for the 2072 bigeye tuna, there is a significant positive correlation between the LDs and lengths at release $(r=0.395, P<0.0001)$. There appears to be a pattern in the data with fish greater than about $70 \mathrm{~cm}$ showing greater LDs than the fish less than about $70 \mathrm{~cm}$.

\subsubsection{Releases at the $155^{\circ} \mathrm{W}$ meridian}

For 1138 fish $\geq 30 \mathrm{DAL}$, released along the $155^{\circ} \mathrm{W}$ meridian, the median DAL was $157 \mathrm{~d}$ (range: 31-1701 d) and the median LD was $667 \mathrm{M}$ (range: $24-4694 \mathrm{M}$ ) (Table 2). 95\% were recaptured within $2943 \mathrm{M}$ of the release position, and $71 \%$ exhibited eastward displacements (Table 2). The fish with the greatest DAL (1701 d) was recaptured by a longline vessel at $1340 \mathrm{M}$, and a bearing of $83^{\circ}$, from the release position. The fish with the greatest LD (4694 M) was recaptured by a purse-seine vessel, at a bearing of $108^{\circ}$ from the release position after 531 DAL. The distribution of recaptures by 1 -degree areas ranges from the most easterly position of $17^{\circ} 26^{\prime}$ $\mathrm{S} 77^{\circ} 33^{\prime} \mathrm{W}$ to the most westerly position of $00^{\circ} 56^{\prime} \mathrm{S} 147^{\circ} 51^{\prime} \mathrm{E}$, and from the most northerly position of $12^{\circ} 46^{\prime} \mathrm{N} 109^{\circ} 51^{\prime} \mathrm{W}$ to the most southerly position of $17^{\circ} 26^{\prime} \mathrm{S} 77^{\circ} 33^{\prime} \mathrm{W}$ (Fig. 4). There is a significant positive correlation between the LDs for the 1138 bigeye tuna and DAL $(r=0.42, P<0.0001)$, which is also evident from the increasing LD statistics, relative to greater DAL categories (Table 2). Although there is only a small range in length, with 1109 (97.5\%) of the 1138 bigeye tuna between 38 and $75 \mathrm{~cm}$, there is a significant negative correlation between the LDs and lengths at release $(r=-0.081, P=0.006)$. There appears to be a pattern in the data, with fish greater than about $60 \mathrm{~cm}$ showing shorter LDs than the fish less than about $60 \mathrm{~cm}$.

\subsubsection{Releases at the $170^{\circ} \mathrm{W}$ meridian}

For 2362 fish $\geq 30 \mathrm{DAL}$, released along the $170^{\circ} \mathrm{W}$ meridian, the median DAL was $184 \mathrm{~d}$ (range: $31-1459 \mathrm{~d}$ ) and the median LD was $952 \mathrm{M}$ (range: 1-5372 M) (Table 2). 95\% were recaptured within $4202 \mathrm{M}$ of the release position, and $49 \%$ exhibited eastward displacements (Table 2). The fish with the greatest DAL (1459 d) was recaptured by a purse-seine vessel $1284 \mathrm{M}$, and a bearing of $85^{\circ}$, from the release position. The fish with the greatest LD $(5372 \mathrm{M})$ was recaptured by a purse-seine vessel, at a bearing of $98^{\circ}$ from the release position after $485 \mathrm{DAL}$. The distribution of recaptures by 1 -degree areas ranges from the most easterly position of $7^{\circ} 50^{\prime}$ $\mathrm{S} 80^{\circ} 47^{\prime} \mathrm{W}$ to the most westerly position of $1^{\circ} 32^{\prime} \mathrm{S} 142^{\circ} 36^{\prime} \mathrm{E}$, and from the most northerly position of $27^{\circ} 03^{\prime} \mathrm{N} 148^{\circ} 41^{\prime} \mathrm{W}$ to the most southerly position of $18^{\circ} 06^{\prime} \mathrm{S} 85^{\circ} 06^{\prime} \mathrm{W}$ (Fig. 5). There is a significant positive correlation between the LDs for the 2405 bigeye tuna and DAL ( $r=0.58, P=<0.0001)$, which is also evident from the increasing LD statistics, relative to greater DAL categories (Table 2). Although there is only a small range in length, with 2305 (97.6\%) 

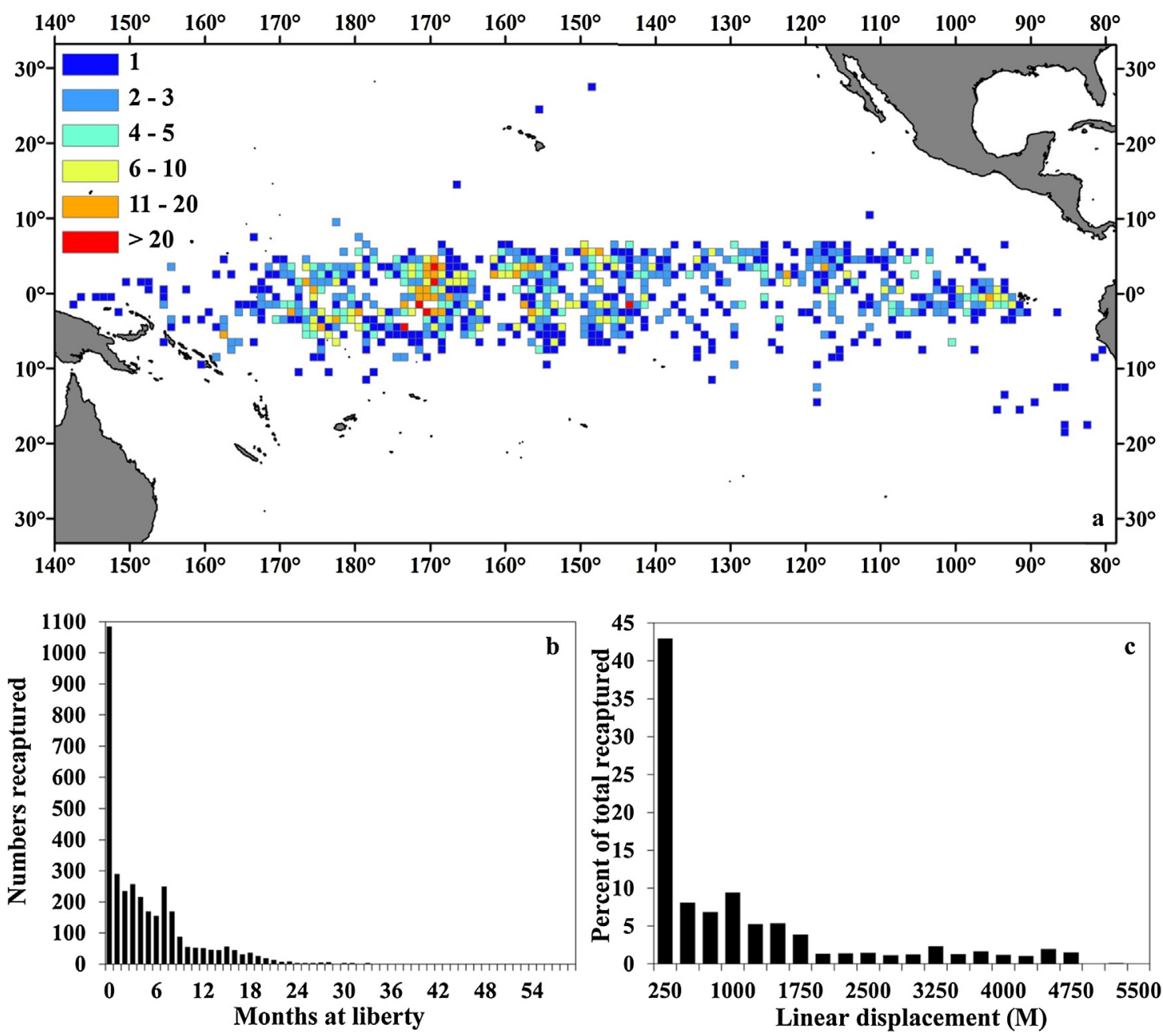

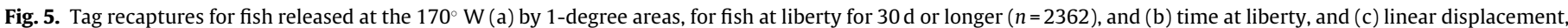
for all recaptures $(n=3446)$.

of the 2362 bigeye tuna between 40 and $80 \mathrm{~cm}$, there is a significant negative correlation between the LDs and lengths at release $(r=-0.08, P<0.0001)$.

\subsubsection{Releases at the $180^{\circ} \mathrm{W}$ meridian}

For 235 fish $\geq 30 \mathrm{DAL}$, released along the $180^{\circ} \mathrm{W}$ meridian, the median DAL was $175 \mathrm{~d}$ (range: $30-893 \mathrm{~d}$ ) and the median LD was $932 \mathrm{M}$ (range: $48-5240 \mathrm{M}$ ) (Table 2). 95\% were recaptured within $4042 \mathrm{M}$ of the release position, and $64 \%$ exhibited eastward displacements (Table 2). The fish with the greatest DAL (893 d) was recaptured by a purse-seine vessel $4591 \mathrm{M}$ and at a bearing of $88^{\circ}$ from the release position. The fish with the greatest LD $(5240 \mathrm{M})$ was also recaptured by a purse-seine vessel, at a bearing of $92^{\circ}$ from the release position after 453 DAL. The distribution of recaptures by 1 -degree areas ranges from the most easterly position of $1^{\circ} 48^{\prime} \mathrm{S} 92^{\circ} 35^{\prime} \mathrm{W}$ to the most westerly position of $00^{\circ} 49^{\prime} \mathrm{N} 145^{\circ} 17^{\prime} \mathrm{E}$, and from the most northerly position of $6^{\circ} 17^{\prime} \mathrm{N} 145^{\circ} 37^{\prime} \mathrm{W}$ to the most southerly position of $8^{\circ} 05^{\prime} \mathrm{S} 174^{\circ} 24^{\prime} \mathrm{E}$ (Fig. 6). There is a significant positive correlation between the LDs for the 235 bigeye tuna and DAL $(r=0.69$, $P<0.0001$ ), which is also evident from the increasing LD statistics, relative to greater DAL categories (Table 2). Although there is only a small range in length with 230 (97.9\%) of the 235 bigeye tuna between 42 and $75 \mathrm{~cm}$, there is a significant negative correlation between the LDs and lengths at release $(r=-0.19, P=0.003)$. There appears to be a pattern in the data, with fish greater than about $60 \mathrm{~cm}$ showing shorter LDs than the fish less than about $60 \mathrm{~cm}$.

\subsubsection{Releases at all four longitudinal meridians}

The percentages of fish recaptured with DTs at less than and greater than $1000 \mathrm{M}$ from each of the four release longitudes, centered along the equator, indicate the amounts of fidelity, dispersion, and mixing with fish from the other release longitudes (Table 3). As for regional fidelity, $43 \%, 71 \%, 52 \%$, and $51 \%$ of the fish released along the $140^{\circ} \mathrm{W}, 155^{\circ} \mathrm{W}, 170^{\circ} \mathrm{W}$, and $180^{\circ}$ meridians, respectively, were recaptured within approximately $1000 \mathrm{M}$ of their release locations. As for dispersion and mixing, for the fish released along the $140^{\circ}$ W, LDs were predominantly eastward ( $76 \%$, Table 2 ), so only $26 \%$, $3 \%$, and $1.5 \%$ of the fish were recaptured within $1000 \mathrm{M}$ of the $155^{\circ}$ $\mathrm{W}, 170^{\circ} \mathrm{W}$, and $180^{\circ}$. For the fish released along the $155^{\circ} \mathrm{W}$, LDs were primarily eastward (71\%, Table 2 ), and although $60 \%$ were recaptured within $1000 \mathrm{M}$ of the $140^{\circ} \mathrm{W}$ meridian, $32 \%$, and $12 \%$ of the fish were recaptured within $1000 \mathrm{M}$ of the $170^{\circ} \mathrm{W}$ and $180^{\circ}$, respectively. For the fish released along the $170^{\circ} \mathrm{W}$, LDs were primarily eastward (66\%, Table 2 ), and $49 \%$, and $25 \%$ of the fish were recaptured within $1000 \mathrm{M}$ of the $155^{\circ} \mathrm{W}$ and $140^{\circ} \mathrm{W}$ meridians, respectively, with $46 \%$ of the fish recaptured within $1000 \mathrm{M}$ of the $180^{\circ}$ meridian. For fish released along $180^{\circ}$, LDs were primarily eastward (64\%, Table 2$)$, and a clear pattern emerges, with $48 \%$, $30 \%$, and $21 \%$ of the fish recaptured within $1000 \mathrm{M}$ of the $170^{\circ} \mathrm{W}$, $155^{\circ} \mathrm{W}$, and $140^{\circ} \mathrm{W}$ meridians, respectively. 

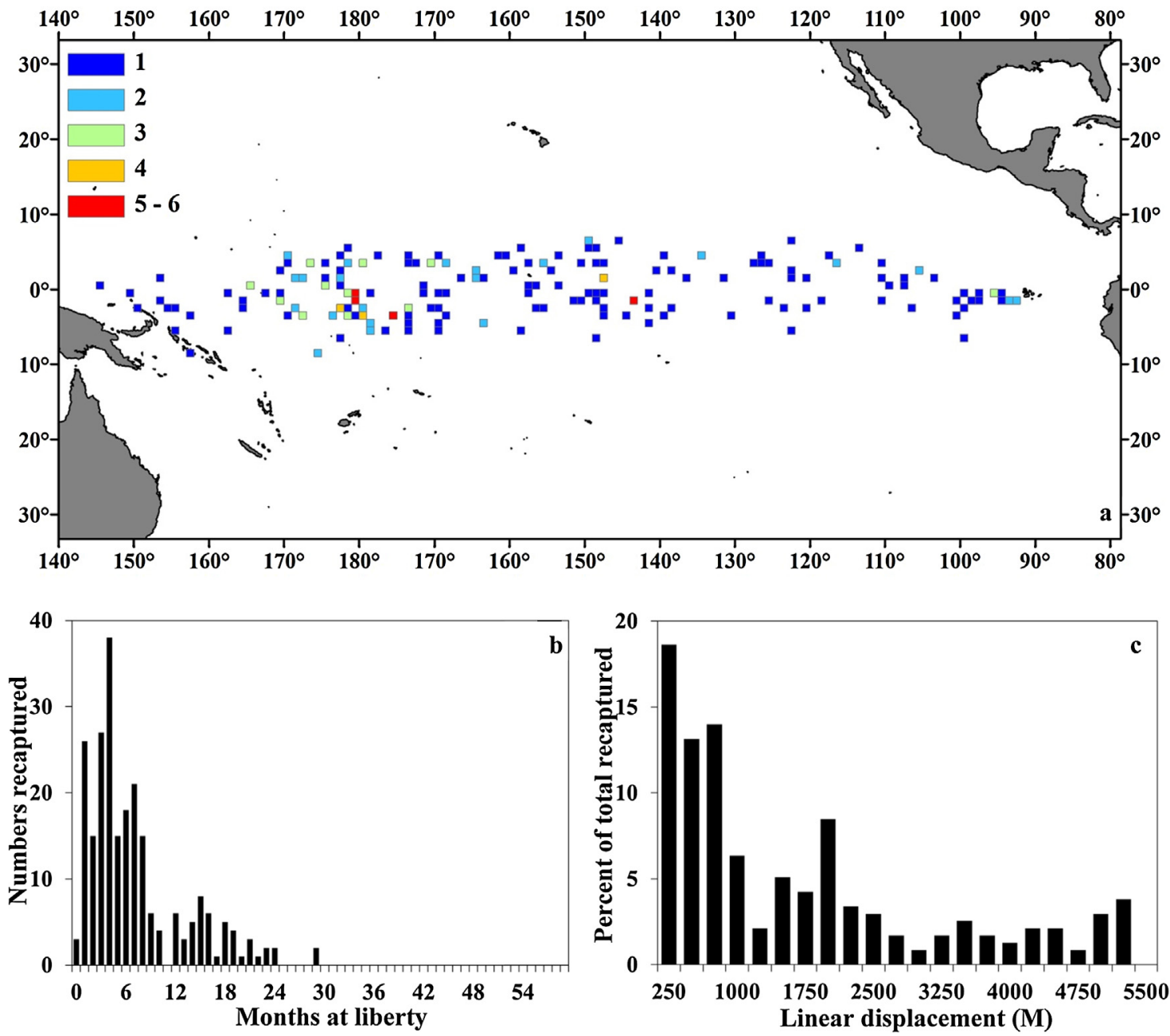

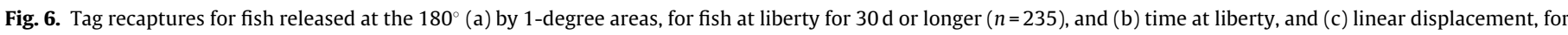
all recaptures $(n=236)$.

The results presented in Figs. 3-6, and Table 3, obtained from tagging experiments with DTs along the $140^{\circ} \mathrm{W}, 155^{\circ} \mathrm{W}$, $170^{\circ} \mathrm{W}$, and $180^{\circ}$ meridians demonstrate constrained latitudinal dispersion, some regional fidelity, some extensive longitudinal dispersion, and substantial mixing of bigeye tuna between these release longitudes. The amount of mixing of bigeye tuna between these release areas in the equatorial CPO, with those in adjacent areas of the equatorial EPO and WPO, is dependent on distances between locations, with, in general, the greatest mixing occurring between the areas that are closest to one another.

\subsection{Releases and recoveries of archival tags}

The numbers of releases of ATs by location, and returns by DAL, and total returns, are given in Table 4. The percentages of AT returns, by release latitudes, along the $140^{\circ} \mathrm{W}, 155^{\circ} \mathrm{W}, 170^{\circ} \mathrm{W}$, and $180^{\circ}$ meridians are mostly lower than the total DT returns from those same locations (Table 1). Of the 90 ATs deployed in bigeye tuna at the $0^{\circ} 140^{\circ} \mathrm{W}, 13.7 \%$ of those were returned, but another $4.4 \%$ of the fish were recaptured and only their DTs returned. Of the 86 ATs deployed in bigeye tuna at the $0^{\circ} 155^{\circ} \mathrm{W}$, although only $5.8 \%$ of those were returned, another $14 \%$ of the total fish were recaptured, and only their DTs returned. Of the 62 ATs deployed at the $2^{\circ} \mathrm{N}$ $170^{\circ} \mathrm{W}, 6.5 \%$ were returned, but another $4.8 \%$ of those same fish were recaptured, and only their DTs returned. These results indicate there was some shedding of ATs, manufactured by both companies. The percentages of total returns, by DAL, show a pattern similar to that observed for the DTs, with the greatest percentage of returns from the category of 180-365 DAL. Of the 449 releases to date, 73 bigeye tuna have been recaptured and their ATs returned, 66

Table 3

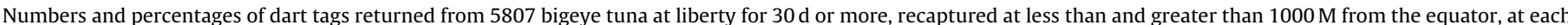
release longitude.

\begin{tabular}{|c|c|c|c|c|c|c|c|c|}
\hline \multirow[t]{3}{*}{ Release longitude } & \multicolumn{8}{|l|}{ Recaptures } \\
\hline & \multicolumn{2}{|l|}{$0^{\circ} 140^{\circ} \mathrm{W}$} & \multicolumn{2}{|l|}{$0^{\circ} 155^{\circ} \mathrm{W}$} & \multicolumn{2}{|l|}{$0^{\circ} 170^{\circ} \mathrm{W}$} & \multicolumn{2}{|l|}{$0^{\circ} 180^{\circ}$} \\
\hline & $<1000$ & $>1000$ & $<1000$ & $>1000$ & $<1000$ & $>1000$ & $<1000$ & $>1000$ \\
\hline $140^{\circ} \mathrm{W}$ & $890(43.0)$ & $1182(57.0)$ & $543(26.2)$ & $1529(73.8)$ & $63(3.0)$ & 2009(97.0) & $31(1.5)$ & $2041(98.5)$ \\
\hline $155^{\circ} \mathrm{W}$ & $767(67.4)$ & $371(32.6)$ & $810(71.2)$ & $328(28.8)$ & $367(32.2)$ & $771(67.8)$ & $141(12.4)$ & $997(87.6)$ \\
\hline $170^{\circ} \mathrm{W}$ & $596(25.2)$ & $1766(74.8)$ & $1149(48.6)$ & $1213(51.4)$ & $1237(52.4)$ & $1125(47.6)$ & $1094(46.3)$ & $1268(53.7)$ \\
\hline $180^{\circ}$ & $52(22.1)$ & $183(77.9)$ & $71(30.2)$ & $164(69.8)$ & $108(48.0)$ & $127(52.0)$ & $120(51.1)$ & $115(48.9)$ \\
\hline
\end{tabular}


(90.4\%) by purse-seine vessels, 1 (1.4\%) by a longline vessel, 1 (1.4\%) by a trolling vessel, and 5 (6.8\%) by undetermined gear types.

\subsubsection{Length distributions of releases by area}

The length-frequency distributions for releases along the $140^{\circ}$ $\mathrm{W}$ and $155^{\circ} \mathrm{W}$, exhibit greater length ranges than for the other areas (Fig. 7). The median length was slightly larger for releases along the $170^{\circ} \mathrm{W}$ meridian, versus the other areas.

\subsubsection{Days at liberty}

Release and recapture information for 48 fish with $\geq 30 \mathrm{DAL}$, from which AT data were recovered, is given in Table 5. The DAL ranged from 36 to $851 \mathrm{~d}$ (mean $=180.6, \mathrm{SE}=21.2$ ), and, except for tag number 1090094, all ATs functioned throughout their deployments.

\subsection{Most probable tracks and movement parameter estimates}

MPTs for the bigeye tuna with the longest LD and longest DAL released along the $140^{\circ} \mathrm{W}$ meridian (Table 5), are plotted in Fig. 8a and b, respectively. The fish in Fig. 8a was recaptured after $248 \mathrm{~d}$ by a purse-seine vessel $2099 \mathrm{M}$ east of the release location, and the fish in Fig. $8 \mathrm{~b}$ was recaptured after $385 \mathrm{~d}$ by a purse-seine vessel $1669 \mathrm{M}$ east of the release location.

MPTs for the bigeye tuna with the longest LD and longest DAL, released along the $155^{\circ} \mathrm{W}$ meridian (Table 5), are plotted in Fig. 9a and b, respectively. The fish in Fig. 9a was recaptured after $237 \mathrm{~d}$ by a purse-seine vessel only $3377 \mathrm{M}$ east of the release location, and the fish in Fig. 9b was recaptured after $287 \mathrm{~d}$ by a purse-seine vessel $524 \mathrm{M}$ east of the release location.

MPTs for the bigeye tuna with the longest LD and longest DAL, released along the $170^{\circ} \mathrm{W}$ meridian (Table 5), are plotted in Fig. 10a and b, respectively. The fish in Fig. 10a was recaptured after $180 \mathrm{~d}$ by a purse-seine vessel $2853 \mathrm{M}$ east of the release location, and the fish in Fig. 10b was recaptured after $553 \mathrm{~d}$ by a purse-seine vessel $1038 \mathrm{M}$ west of the release location.

MPTs for two bigeye tuna released along the $180^{\circ}$ meridian (Table 5), are plotted in Fig. 11a and b. The fish in Fig. 11a was recaptured after $225 \mathrm{~d}$ by a purse-seine vessel $1323 \mathrm{M}$ east of the release location, and the fish in Fig. 11b was recaptured after $241 \mathrm{~d}$ by a purse-seine vessel $1561 \mathrm{M}$ east of the release location.

For the fish released with ATs along the $140^{\circ} \mathrm{W}, 155^{\circ} \mathrm{W}, 170^{\circ}$ $\mathrm{W}$, and $180^{\circ}$ meridians (Table 5 ), the improved position estimates along the MPTs are illustrated in Fig. 12, and the corresponding statistics describing the movements and dispersion are given in Table 6 , by release longitude. The $95 \%$ volume contours, encompassing the position estimates from the releases along the $140^{\circ}$ $\mathrm{W}, 155^{\circ} \mathrm{W}, 170^{\circ} \mathrm{W}$, and $180^{\circ}$ meridians, show considerable overlap, demonstrating mixing of fish from these release longitudes (Fig. 12e). The results presented in Fig. 12 and Table 6, from the tagging experiments with ATs, demonstrate constrained latitudinal dispersion, some regional fidelity, some extensive longitudinal dispersion, and substantial mixing of bigeye tuna among these release longitudes in the equatorial CPO.

The parameter estimates from the UKFsst for errors in longitude $\left(\sigma_{x}\right)$ and latitude $\left(\sigma_{y}\right)$, eastward and northward directed movements ( $u$ and $v$ ) and dispersive movement $(D)$ are summarized by area of release and for all fish pooled in Table 7. Although counterintuitive, eastward directed movement $(u)$ is defined by a negative value, but northward directed movement $(v)$ is defined by a positive value. The estimated dispersive movement parameter $(D)$ is slightly greater for the fish released along the $140^{\circ} \mathrm{W}$ meridian, than for the other release areas. The median parameter estimates obtained from the pooled data indicate that the expected error in position

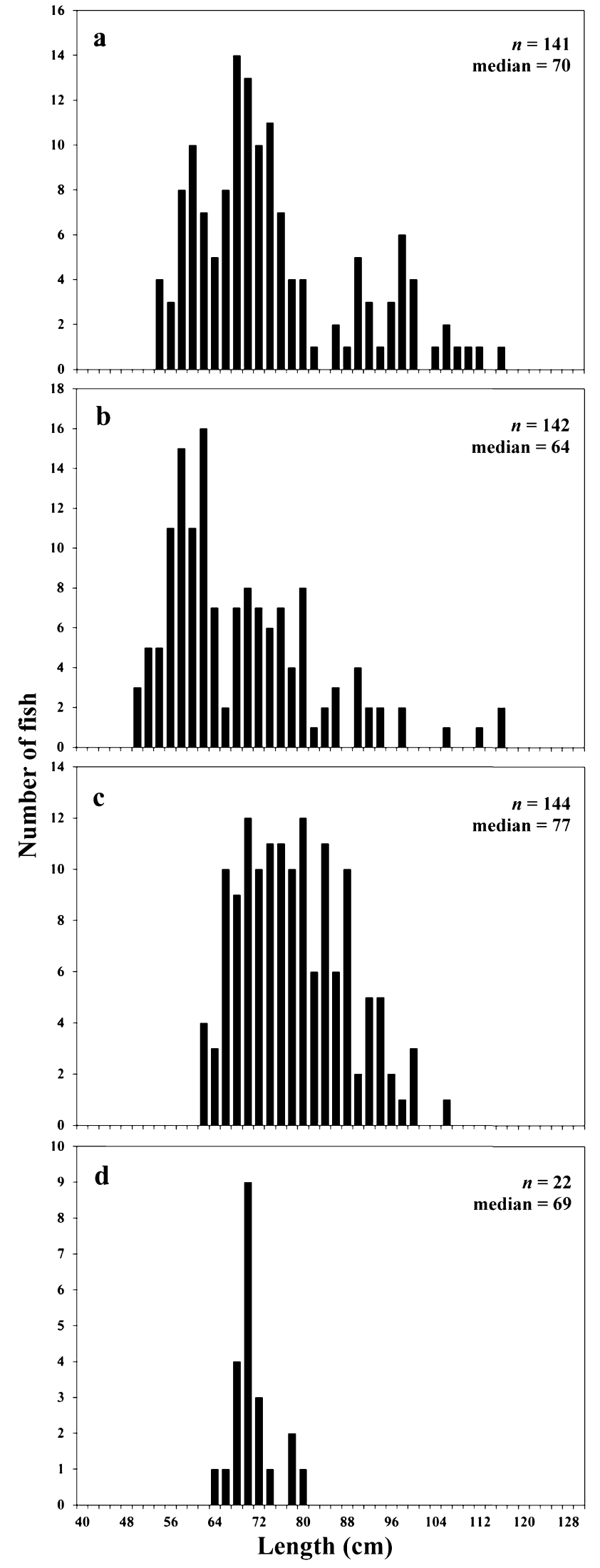

Fig. 7. Length-frequency distributions of fish released with archival tags at (a) $140^{\circ}$ $\mathrm{W}$, (b) $155^{\circ} \mathrm{W}$, (c) $170^{\circ} \mathrm{W}$, and (d) $180^{\circ}$. 
Table 4

Releases and returns of archival tags, by area, and days at liberty.

\begin{tabular}{|c|c|c|c|c|c|c|c|}
\hline \multirow[t]{2}{*}{ Area } & \multirow[t]{2}{*}{ Released } & \multicolumn{6}{|c|}{ Returned } \\
\hline & & $<30$ & $30-89$ & $90-179$ & $180-365$ & $>365$ & Total (\%) \\
\hline $2^{\circ} \mathrm{S} 140^{\circ} \mathrm{W}$ & 16 & 0 & 0 & 0 & 1 & 0 & $1(6.3)$ \\
\hline $0^{\circ} 140^{\circ} \mathrm{W}$ & 90 & 2 & 2 & 5 & 4 & 0 & $13(14.4)$ \\
\hline $2^{\circ} \mathrm{N} 140^{\circ} \mathrm{W}$ & 35 & 5 & 1 & 4 & 4 & 1 & $15(42.9)$ \\
\hline $0^{\circ} 155^{\circ} \mathrm{W}$ & 86 & 3 & 1 & 1 & 0 & 0 & $5(5.8)$ \\
\hline $2^{\circ} \mathrm{N} 155^{\circ} \mathrm{W}$ & 37 & 0 & 1 & 3 & 5 & 0 & $9(24.3)$ \\
\hline $5^{\circ} \mathrm{N} 155^{\circ} \mathrm{W}$ & 6 & 0 & 1 & 0 & 0 & 0 & $1(16.7)$ \\
\hline $8^{\circ} \mathrm{N} 155^{\circ} \mathrm{W}$ & 13 & 0 & 2 & 0 & 2 & 1 & $5(38.5)$ \\
\hline $2^{\circ} \mathrm{S} 170^{\circ} \mathrm{W}$ & 23 & 5 & 1 & 1 & 0 & 1 & $8(34.8)$ \\
\hline $0^{\circ} 170^{\circ} \mathrm{W}$ & 59 & 1 & 3 & 3 & 2 & 1 & $10(16.9)$ \\
\hline $2^{\circ} \mathrm{N} 170^{\circ} \mathrm{W}$ & 62 & 1 & 1 & 0 & 1 & 1 & $4(6.5)$ \\
\hline $2^{\circ} \mathrm{S} 180^{\circ}$ & 7 & 1 & 0 & 0 & 0 & 0 & $1(14.3)$ \\
\hline $0^{\circ} 180^{\circ}$ & 15 & 0 & 0 & 0 & 2 & 0 & $2(13.3)$ \\
\hline All & 449 & 18 & 13 & 17 & 21 & 5 & $74(16.5)$ \\
\hline
\end{tabular}

Table 5

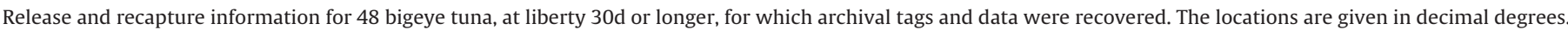

\begin{tabular}{|c|c|c|c|c|c|c|c|c|c|c|}
\hline \multirow{3}{*}{$\begin{array}{l}\text { Tag no. } \\
\text { D5136 }\end{array}$} & \multicolumn{4}{|l|}{ Release } & \multicolumn{4}{|l|}{ Recapture } & \multirow{3}{*}{$\begin{array}{l}\text { Days at liberty } \\
36\end{array}$} & \multirow{3}{*}{$\begin{array}{l}\text { Tag duration } \\
36\end{array}$} \\
\hline & \multirow{2}{*}{$\begin{array}{l}\text { Date } \\
\text { 5-Jun-09 }\end{array}$} & \multicolumn{2}{|c|}{ Location (dd) } & \multirow{2}{*}{$\begin{array}{l}\text { Length }(\mathrm{cm}) \\
56\end{array}$} & \multirow{2}{*}{$\begin{array}{l}\text { Date } \\
11 \text {-Jul-09 }\end{array}$} & \multicolumn{2}{|c|}{ Location (dd) } & \multirow{2}{*}{$\frac{\text { Length }(\mathrm{cm})}{57}$} & & \\
\hline & & $0.03 \mathrm{~N}$ & $140.03 \mathrm{~W}$ & & & $1.70 \mathrm{~S}$ & $124.50 \mathrm{~W}$ & & & \\
\hline D5488 & 5-Jun-09 & $0.03 \mathrm{~N}$ & $140.03 \mathrm{~W}$ & 60 & 3-Dec-09 & $0.13 \mathrm{~N}$ & $109.43 \mathrm{~W}$ & 74 & 181 & 181 \\
\hline D5480 & 6-Jun-09 & $0.03 \mathrm{~N}$ & $140.03 \mathrm{~W}$ & 92 & 13-Oct-09 & $2.02 \mathrm{~N}$ & $131.00 \mathrm{~W}$ & 99 & 129 & 129 \\
\hline D5485 & 6-Jun-09 & $0.03 \mathrm{~N}$ & $140.03 \mathrm{~W}$ & 88 & 15-Sep-09 & $0.70 \mathrm{~N}$ & $140.77 \mathrm{~W}$ & $97^{\mathrm{a}}$ & 101 & 101 \\
\hline D5511 & 6-Jun-09 & $0.03 \mathrm{~N}$ & $140.03 \mathrm{~W}$ & 86 & 22-Oct-09 & $2.50 \mathrm{~S}$ & $134.07 \mathrm{~W}$ & $99^{\mathrm{a}}$ & 138 & 138 \\
\hline 990298 & 24-Oct-09 & $2.03 \mathrm{~S}$ & $140.17 \mathrm{~W}$ & 65 & 27-May-10 & $4.70 \mathrm{~S}$ & $123.87 \mathrm{~W}$ & 82 & 215 & 215 \\
\hline 990315 & 26-Oct-09 & $1.98 \mathrm{~N}$ & $140.01 \mathrm{~W}$ & 63 & 15-Jul-10 & $2.22 \mathrm{~N}$ & $141.62 \mathrm{~W}$ & 79 & 262 & 262 \\
\hline 990296 & 26-Oct-09 & $1.98 \mathrm{~N}$ & $140.01 \mathrm{~W}$ & 72 & 5-Apr-10 & $2.75 \mathrm{~S}$ & $139.87 \mathrm{~W}$ & $88^{a}$ & 161 & 161 \\
\hline D5515 & 26-Oct-09 & $1.98 \mathrm{~N}$ & $140.01 \mathrm{~W}$ & 58 & 16-Dec-09 & $3.52 \mathrm{~N}$ & $142.02 \mathrm{~W}$ & $63^{a}$ & 51 & 51 \\
\hline 990289 & 26-Oct-09 & $1.98 \mathrm{~N}$ & $140.01 \mathrm{~W}$ & 69 & 15-Nov-10 & $3.88 \mathrm{~N}$ & $112.23 \mathrm{~W}$ & $106^{\mathrm{a}}$ & 385 & 385 \\
\hline D4877 & 26-Oct-09 & $1.98 \mathrm{~N}$ & $140.01 \mathrm{~W}$ & 75 & 25-Jan-10 & $2.12 \mathrm{~S}$ & $135.60 \mathrm{~W}$ & $88^{\mathrm{a}}$ & 91 & 91 \\
\hline A0109 & 27-Oct-09 & $1.98 \mathrm{~N}$ & $140.01 \mathrm{~W}$ & 68 & 9-Aug-10 & $1.88 \mathrm{~S}$ & $116.60 \mathrm{~W}$ & 90 & 286 & 286 \\
\hline A0123 & 27-Oct-09 & $1.98 \mathrm{~N}$ & $140.01 \mathrm{~W}$ & 59 & 8-Mar10 & $5.23 \mathrm{~N}$ & $122.80 \mathrm{~W}$ & $72^{\mathrm{a}}$ & 132 & 132 \\
\hline 1190185 & 13-Nov-11 & $0.02 \mathrm{~N}$ & $139.92 \mathrm{~W}$ & 79 & 18-Jul-12 & $1.87 \mathrm{~S}$ & $104.98 \mathrm{~W}$ & 99 & 248 & 248 \\
\hline 1190151 & 13-Nov-11 & $0.02 \mathrm{~N}$ & $139.92 \mathrm{~W}$ & 67 & 15-Apr-12 & $3.57 \mathrm{~S}$ & $119.15 \mathrm{~W}$ & 80 & 154 & 154 \\
\hline 1190166 & 13-Nov-11 & $0.02 \mathrm{~N}$ & $139.92 \mathrm{~W}$ & 76 & 23-Mar-12 & $3.93 \mathrm{~N}$ & $125.38 \mathrm{~W}$ & 83 & 131 & 131 \\
\hline 890002 & 11-May-08 & $5.03 \mathrm{~N}$ & $154.95 \mathrm{~W}$ & 68 & 11-Jul-08 & $3.68 \mathrm{~N}$ & $158.12 \mathrm{~W}$ & $74^{\mathrm{a}}$ & 61 & 61 \\
\hline 890006 & 16-May-08 & $1.99 \mathrm{~N}$ & $154.96 \mathrm{~W}$ & 73 & 27-Feb-09 & $4.77 \mathrm{~N}$ & $146.68 \mathrm{~W}$ & $100^{\mathrm{a}}$ & 287 & 287 \\
\hline 890010 & 16-May-08 & $1.99 \mathrm{~N}$ & $154.96 \mathrm{~W}$ & 72 & 25-Feb-09 & $1.50 \mathrm{~N}$ & $153.35 \mathrm{~W}$ & $99^{a}$ & 285 & 285 \\
\hline 890020 & 16-Мay-08 & $1.99 \mathrm{~N}$ & $154.96 \mathrm{~W}$ & 70 & 28-Jul-08 & $1.95 \mathrm{~S}$ & $152.50 \mathrm{~W}$ & $77^{\mathrm{a}}$ & 73 & 73 \\
\hline 890032 & 17-May-08 & $1.99 \mathrm{~N}$ & $154.97 \mathrm{~W}$ & 86 & 6-Sep-08 & $1.93 \mathrm{~S}$ & $168.13 \mathrm{~W}$ & $96^{\mathrm{a}}$ & 112 & 112 \\
\hline 890031 & 17-May-08 & $1.99 \mathrm{~N}$ & $154.97 \mathrm{~W}$ & 77 & 26-Dec-08 & $0.53 \mathrm{~N}$ & $164.42 \mathrm{~W}$ & $98^{\mathrm{a}}$ & 223 & 223 \\
\hline 890033 & 17-May-08 & $2.00 \mathrm{~N}$ & $155.00 \mathrm{~W}$ & 85 & 26-Nov-08 & $3.07 \mathrm{~S}$ & $148.95 \mathrm{~W}$ & $103^{a}$ & 193 & 193 \\
\hline 890035 & 18-Мay-08 & $1.99 \mathrm{~N}$ & $154.96 \mathrm{~W}$ & 106 & 19-Aug-08 & $2.75 \mathrm{~N}$ & $155.67 \mathrm{~W}$ & $114^{\mathrm{a}}$ & 93 & 93 \\
\hline 890041 & 24-May-08 & $1.99 \mathrm{~N}$ & $154.96 \mathrm{~W}$ & 79 & 18-Sep-08 & $1.29 \mathrm{~S}^{\mathrm{b}}$ & $161.04 \mathrm{~W}^{\mathrm{b}}$ & $90^{\mathrm{a}}$ & 117 & 117 \\
\hline 890047 & 24-May-08 & $1.99 \mathrm{~N}$ & $154.96 \mathrm{~W}$ & 83 & 18-Dec-08 & $0.83 \mathrm{~S}$ & $166.52 \mathrm{~W}$ & $102^{\mathrm{a}}$ & 208 & 208 \\
\hline 990115 & 26-May-09 & $0.01 \mathrm{~N}$ & $153.88 \mathrm{~W}$ & 58 & 26-Oct-09 & $0.83 \mathrm{~N}$ & $149.15 \mathrm{~W}$ & $73^{a}$ & 153 & 153 \\
\hline 890252 & $12-0 c t-09$ & $0.02 \mathrm{~N}$ & $154.98 \mathrm{~W}$ & 82 & 19-Nov-09 & $1.83 \mathrm{~N}$ & $149.63 \mathrm{~W}$ & $85^{\mathrm{a}}$ & 38 & 38 \\
\hline A0576 & 5-Dec-11 & $8.00 \mathrm{~N}$ & $155.01 \mathrm{~W}$ & 51 & 3-Feb-12 & $3.68 \mathrm{~N}$ & $155.28 \mathrm{~W}$ & $57^{a}$ & 60 & 60 \\
\hline A0720 & 7-Dec-11 & $7.85 \mathrm{~N}$ & $154.98 \mathrm{~W}$ & 51 & 31-Jul-12 & $0.60 \mathrm{~S}$ & 099.15 W & 71 & 237 & 237 \\
\hline A0738 & 10-Dec-11 & $7.98 \mathrm{~N}$ & $155.03 \mathrm{~W}$ & 51 & 7-Feb-12 & $5.95 \mathrm{~S}$ & $158.75 \mathrm{~W}$ & 54 & 59 & 59 \\
\hline 1090090 & 12-May-10 & $2.01 \mathrm{~N}$ & $170.03 \mathrm{~W}$ & 85 & 19-Jun-10 & $4.92 \mathrm{~N}$ & $161.35 \mathrm{~W}$ & 83 & 38 & 38 \\
\hline 890245 & 22-Nov-10 & $2.17 \mathrm{~S}$ & $170.03 \mathrm{~W}$ & 63 & 3-Feb-11 & $2.32 \mathrm{~S}$ & $174.92 \mathrm{~W}$ & $70^{\mathrm{a}}$ & 73 & 38 \\
\hline 890255 & 22-Nov-10 & $2.17 \mathrm{~S}$ & $170.03 \mathrm{~W}$ & 75 & 28-May-12 & $1.72 \mathrm{~S}$ & $172.66 \mathrm{E}$ & $124^{\mathrm{a}}$ & 553 & 553 \\
\hline 1090336 & 24-Nov-10 & $0.03 \mathrm{~S}$ & $170.06 \mathrm{~W}$ & 80 & 3-Feb-11 & $2.32 \mathrm{~S}$ & $174.92 \mathrm{~W}$ & $87^{a}$ & 71 & 71 \\
\hline 1090366 & 24-Nov-10 & $0.03 \mathrm{~S}$ & $170.17 \mathrm{~W}$ & 96 & 23-May-11 & $2.72 \mathrm{~N}$ & $122.68 \mathrm{~W}$ & 101 & 180 & 180 \\
\hline 1090198 & 24-Nov-10 & $0.03 \mathrm{~S}$ & $170.17 \mathrm{~W}$ & 106 & 19-Nov-11 & $0.52 \mathrm{~N}$ & $156.37 \mathrm{~W}$ & $134^{\mathrm{a}}$ & 360 & 360 \\
\hline 1090094 & 27-Nov-10 & $2.02 \mathrm{~N}$ & $170.03 \mathrm{~W}$ & 87 & 27-Mar-13 & $2.48 \mathrm{~S}$ & $154.50 \mathrm{~W}$ & 156 & 851 & 473 \\
\hline 1090337 & 27-Nov-10 & $2.02 \mathrm{~N}$ & $170.03 \mathrm{~W}$ & 84 & 16-Aug-11 & $4.87 \mathrm{~N}$ & $146.58 \mathrm{~W}$ & 104 & 262 & 262 \\
\hline 1090443 & 11-Oct-11 & $0.02 \mathrm{~S}$ & $170.04 \mathrm{~W}$ & 77 & 22-Jan-12 & $0.07 \mathrm{~N}$ & $164.58 \mathrm{~W}$ & 84 & 103 & 103 \\
\hline 1190024 & 11-Oct-11 & $0.02 \mathrm{~S}$ & $170.04 \mathrm{~W}$ & 76 & 23-Jan-12 & $0.53 \mathrm{~N}$ & $166.57 \mathrm{~W}$ & 78 & 104 & 104 \\
\hline 1090470 & 11-Oct-11 & $0.02 \mathrm{~S}$ & $170.04 \mathrm{~W}$ & 78 & 13-Jan-11 & $2.04 \mathrm{~N}$ & $157.50 \mathrm{~W}$ & $84^{\mathrm{a}}$ & 58 & 58 \\
\hline 1090430 & 14-Oct-11 & $0.03 \mathrm{~S}$ & $170.04 \mathrm{~W}$ & 72 & 10-Dec-11 & $3.02 \mathrm{~N}$ & $173.17 \mathrm{~W}$ & $77^{\mathrm{a}}$ & 57 & 57 \\
\hline 1090337 & $1-$ Oct-12 & $2.15 \mathrm{~S}$ & $170.03 \mathrm{~W}$ & 61 & 22-Feb-13 & $0.35 \mathrm{~N}$ & $166.79 \mathrm{E}$ & $72^{\mathrm{a}}$ & 113 & 113 \\
\hline 1190132 & $3-O c t-12$ & $0.05 \mathrm{~S}$ & $170.05 \mathrm{~W}$ & 67 & 19-Jan-13 & $0.94 \mathrm{~S}$ & $173.43 \mathrm{~W}$ & $78^{a}$ & 108 & 108 \\
\hline 1190134 & 3-Oct-12 & $0.05 \mathrm{~S}$ & $170.05 \mathrm{~W}$ & 69 & $9-O c t-13$ & $2.47 \mathrm{~S}$ & $146.97 \mathrm{~W}$ & 88 & 371 & 371 \\
\hline 1090429 & 19-Oct-11 & $0.02 \mathrm{~S}$ & $179.90 \mathrm{~W}$ & 68 & 31-May-12 & $0.13 \mathrm{~N}$ & $157.85 \mathrm{~W}$ & $90^{\mathrm{a}}$ & 225 & 225 \\
\hline 1190170 & 20-Oct-11 & $0.02 \mathrm{~S}$ & $179.91 \mathrm{~W}$ & 70 & 17-Jun-12 & $2.82 \mathrm{~N}$ & $154.04 \mathrm{~W}$ & 86 & 241 & 241 \\
\hline
\end{tabular}

a Predicted length from the growth model of Aires-da-Silva et al. (2014).

b Recovery position estimated from the UKFsst model. 


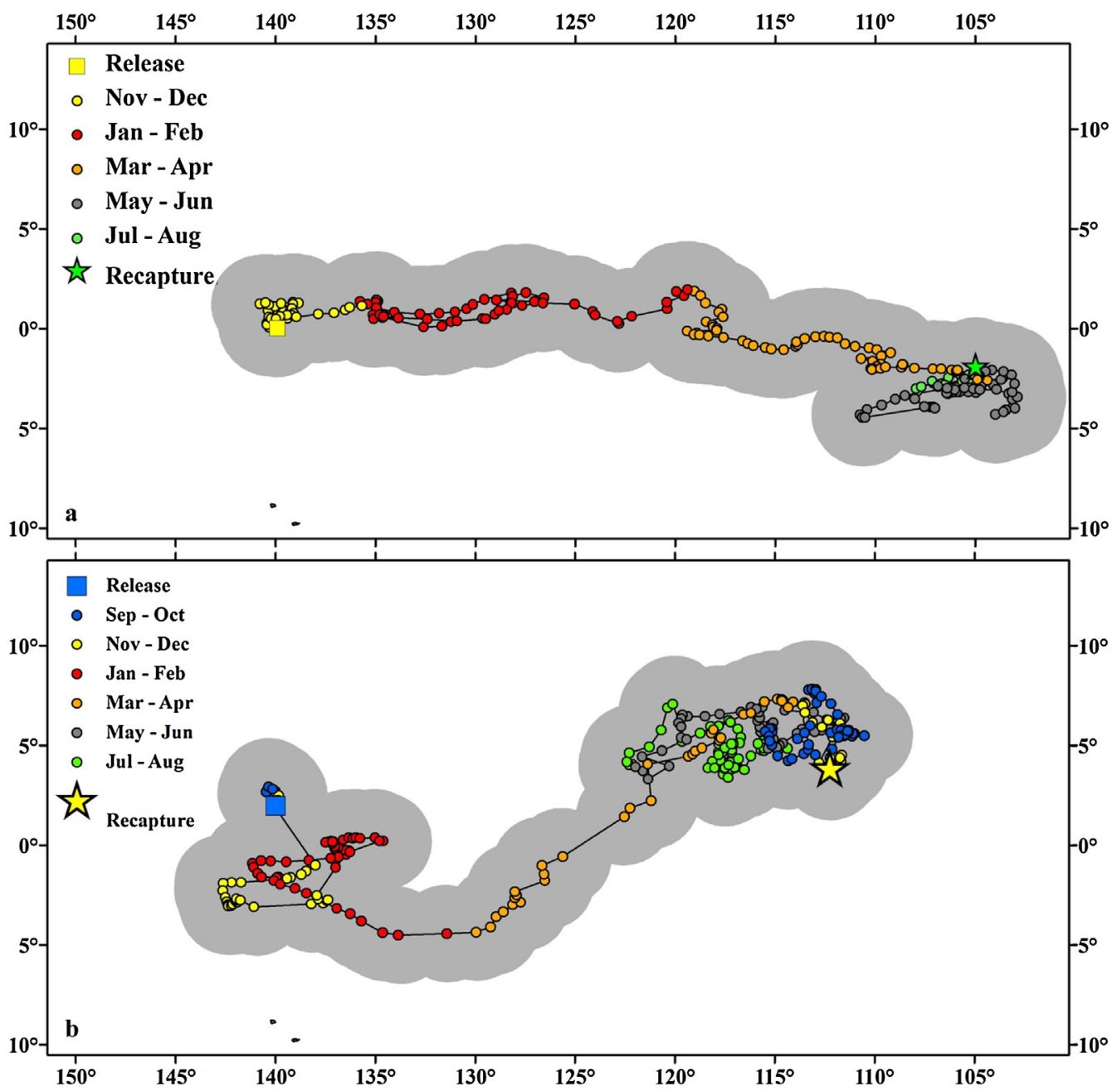

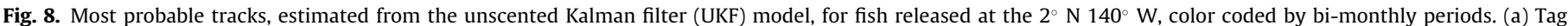

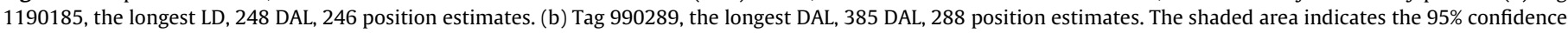
interval estimated by the UKF model. (For interpretation of the references to color in figure legend, the reader is referred to the web version of the article.)

estimates along MPTs should be within about $31 \mathrm{M}$ in longitude and $105 \mathrm{M}$ in latitude, with a daily linear displacement of about $22 \mathrm{M}$.

\section{Discussion}

The results from tagging experiments in this study, based on relatively large numbers of DT and AT releases and recaptures, conducted over a period of several years, are informative for describing the movements, dispersion, and mixing of bigeye tuna in the equatorial $\mathrm{CPO}$, and with those from adjacent areas. These tagging data demonstrate constrained latitudinal dispersion, some regional fidelity, some extensive eastward longitudinal dispersion, and substantial mixing of bigeye tuna between release longitudes. The amount of mixing of bigeye tuna between the release areas in the equatorial CPO, with those in adjacent areas of the equatorial EPO and WPO, is dependent on distances between areas, with, in general, the greatest mixing occurring between the areas that are closest to one another.

\subsection{Dart tags}

Comprehensive screening of the bigeye tuna DT recapture data was implemented in this study, to filter out erroneous data, which results from the wrong purse-seine vessel name and/or well number reported by finders when returning DTs. Initially all reported
DT recapture data were cross-validated against either vessel logbooks, observer set summaries, or VMS records. However, since tag seeding experiments conducted during the PTTP, demonstrated an average error rate of about $30 \%$ in reporting the vessel name (Leroy et al., 2013), and vessel names and well numbers reported with DTs recovered from transshipment vessels are unreliable, it is critical to carefully scrutinize DT recapture data to obtain a subset of high-confidence data.

We first excluded the DT data reported to have been recovered from transshipment vessels. For the 1528 DTs recovered during transshipments, $155(10.1 \%)$ had recapture dates and positions assigned. Applying the previously described filtering procedures, to the 155 DTs, resulted in the elimination of an additional 71 DTs, yielding a total of 84 , of which 83 were $\geq 30$ DAL. Therefore, exclusion of the DT data recovered during the time of transshipments does not have any bias on the movement patterns described in this study.

The appointment of tag recovery officers (TROs) in key ports for daily monitoring of unloading of purse-seine vessels, so as to collect reliable DT recovery data directly from finders, and pay rewards, has proven to be effective during the PTTP, and instrumental to this study (Leroy et al., 2013). The DT recapture data obtained from the TRO in Manta, Ecuador, along with other reliable DT recapture data obtained from observers aboard purse-seine vessels, were used to construct speed filters (M/d) for LDs, by DAL, for 

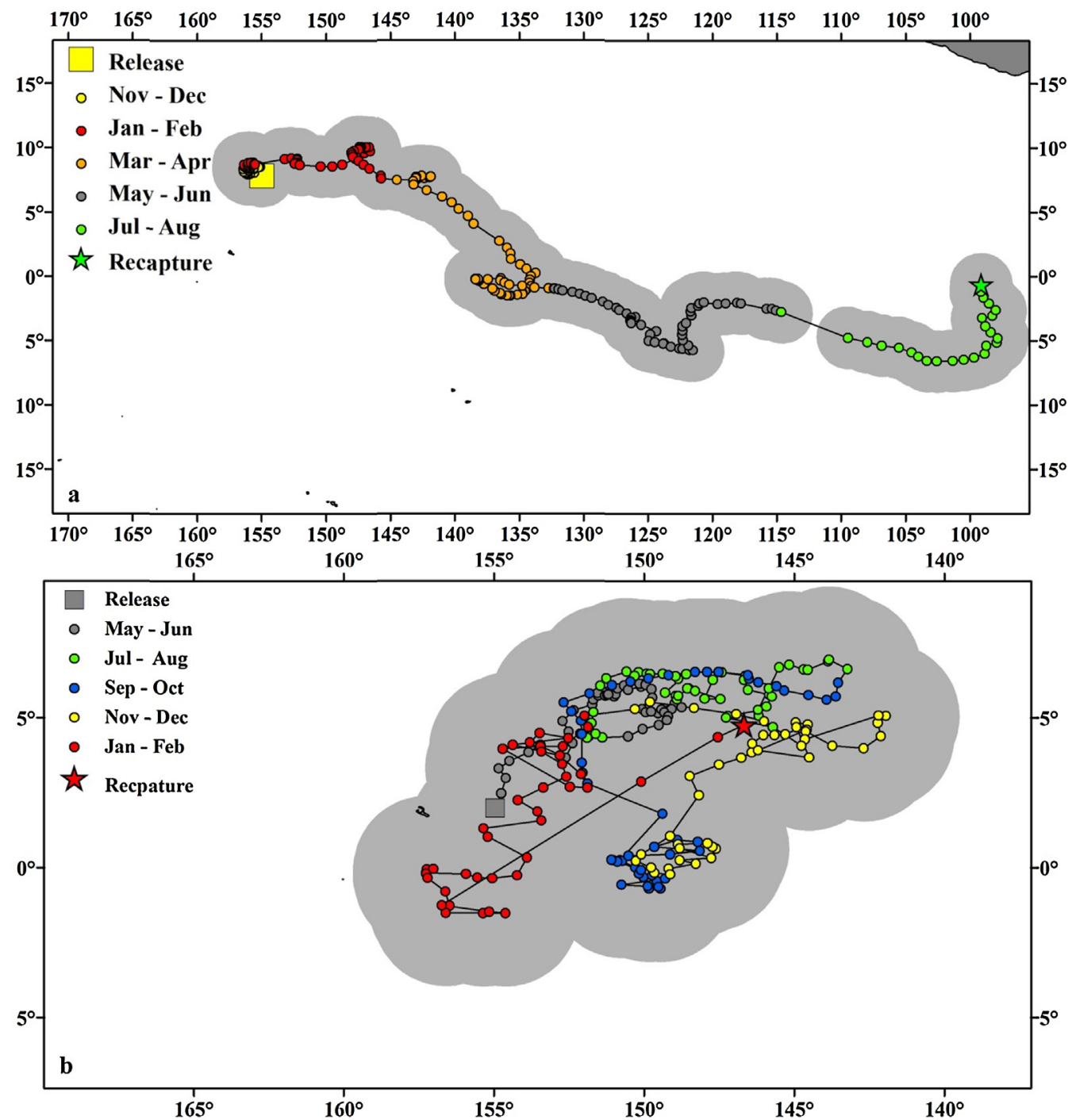

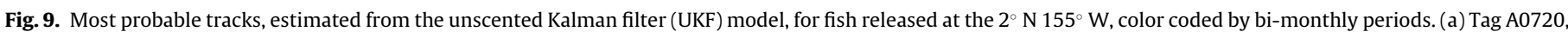

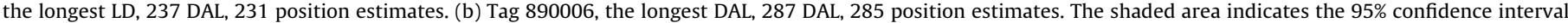
estimated by the UKF model. (For interpretation of the references to color in figure legend, the reader is referred to the web version of the article.)

final screening of the other DT recapture data. The use of a speed filter to detect and eliminate unrealistic LDs, provided a subset of high-confidence recapture data, including dates, locations, and fish lengths. Regardless of the fact that we have made every reasonable attempt in this study to screen and filter the DT data, we realize that this subset may still have some biases resulting from fishing effort distributions, selectivity, reporting rates, and some undetected erroneous recapture data.

Results in this study, from tagging experiments using DTs, demonstrated that for 5807 fish with $\geq 30$ DAL, the median LD was $936 \mathrm{M}$ and $95 \%$ of the fish were recaptured up to $3614 \mathrm{M}$ from their release locations. $71 \%$ of the LDs were in an eastward direction, and

Table 6

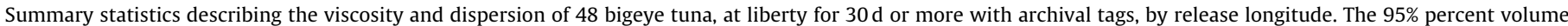
contours were calculated from a kernel density function for all positions, along most probable tracks, utilizing a $1^{\circ}$ search radius and a $0.01^{\circ}$ output cell size.

\begin{tabular}{|c|c|c|c|c|}
\hline \multirow[t]{2}{*}{ Parameter } & \multicolumn{4}{|c|}{ Release longitude } \\
\hline & $140^{\circ} \mathrm{W}$ & $155^{\circ} \mathrm{W}$ & $170^{\circ} \mathrm{W}$ & $180^{\circ}$ \\
\hline Number of fish & 16 & 15 & 15 & 2 \\
\hline Mean days at liberty & 168.8 & 146.6 & 220.1 & 233.0 \\
\hline Range of days at liberty & $36-385$ & $38-287$ & $38-851$ & $225-241$ \\
\hline Latitude range & $8^{\circ} \mathrm{N}-5^{\circ} \mathrm{S}$ & $10^{\circ} \mathrm{N}-6^{\circ} \mathrm{S}$ & $7^{\circ} \mathrm{N}-7^{\circ} \mathrm{S}$ & $5^{\circ} \mathrm{N}-4^{\circ} \mathrm{S}$ \\
\hline Longitude range & $103^{\circ}-155^{\circ} \mathrm{W}$ & $99^{\circ}-172^{\circ} \mathrm{W}$ & $109^{\circ} \mathrm{W}-165^{\circ} \mathrm{E}$ & $154^{\circ} \mathrm{W}-172^{\circ} \mathrm{E}$ \\
\hline Number (\%) of fish remaining within $1000 \mathrm{M}$ of release position & $9(56)$ & $13(87)$ & $7(47)$ & $0(0)$ \\
\hline Percentage of positions eastward & 70.8 & 64.1 & 68.8 & 76.7 \\
\hline $95 \%$ of positions are within (M) & 1763 & 1252 & 3073 & 1140 \\
\hline $95 \%$ volume contour $\left(\mathrm{M}^{2}\right)$ & $1,931,509$ & $1,561,508$ & 263,6621 & 71,953 \\
\hline $95 \%$ volume contour center & $1^{\circ} \mathrm{N} 129^{\circ} \mathrm{W}$ & $1^{\circ} \mathrm{N} 150^{\circ} \mathrm{W}$ & $1^{\circ} \mathrm{N} 152^{\circ} \mathrm{W}$ & $1^{\circ} \mathrm{S} 172^{\circ} \mathrm{W}$ \\
\hline
\end{tabular}




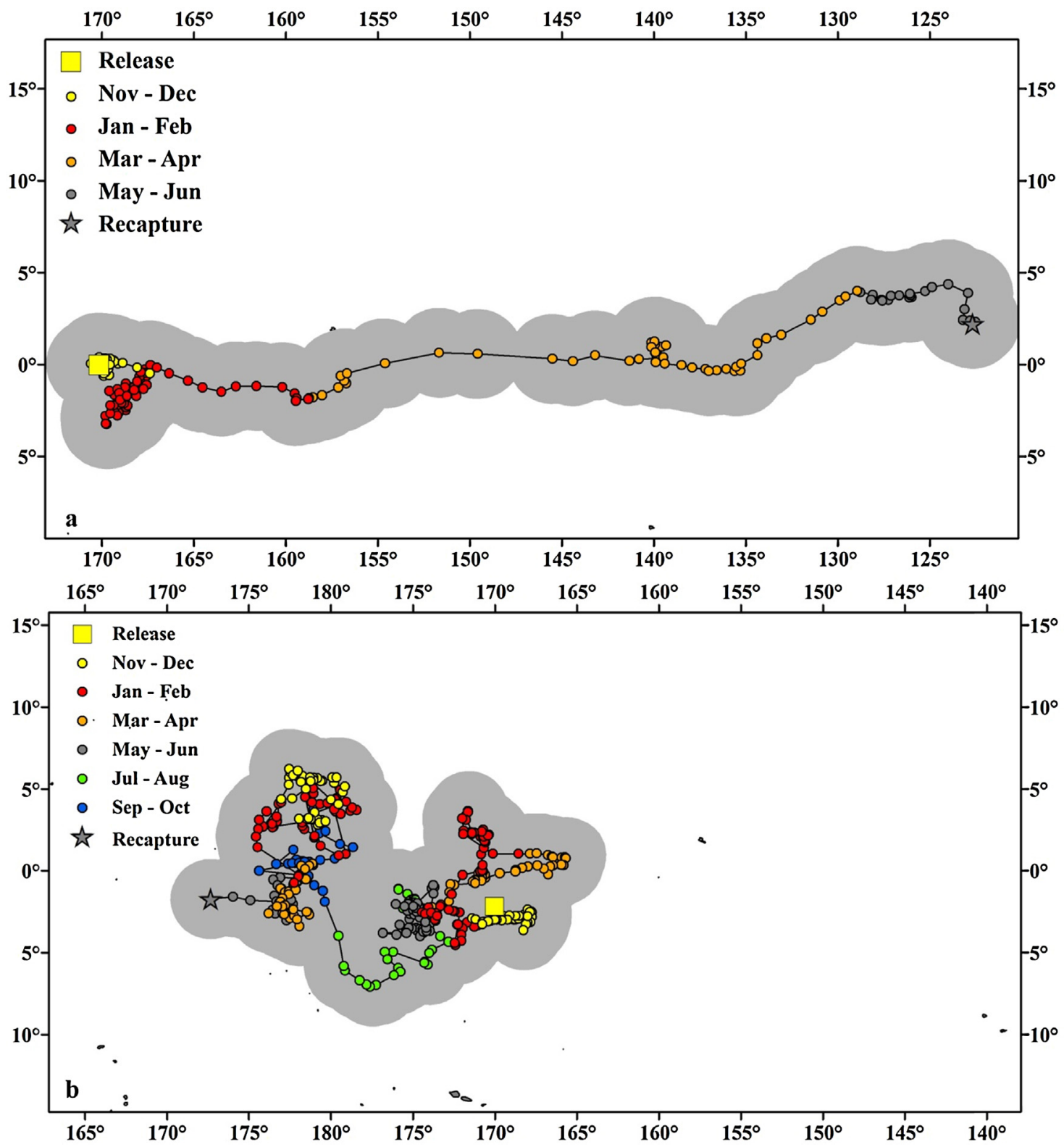

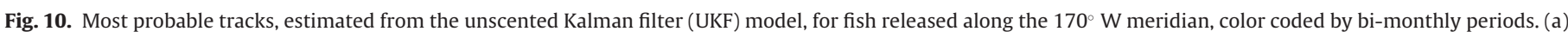

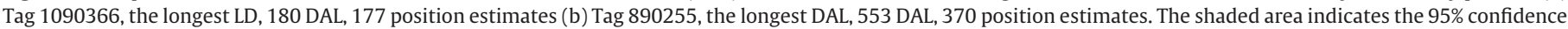
interval estimated by the UKF model. (For interpretation of the references to color in figure legend, the reader is referred to the web version of the article.)

Table 7

Summary of the movement parameter estimates from the unscented Kalman filter model, for all bigeye tuna listed in Table 5.

\begin{tabular}{|c|c|c|c|c|c|c|c|}
\hline Release & $n$ & & $\sigma_{x}($ degrees $)$ & $\sigma_{y}$ (degrees) & $u(\mathrm{M} / \mathrm{d})$ & $v(\mathrm{M} / \mathrm{d})$ & $D\left(\mathrm{M}^{2} / \mathrm{d}\right)$ \\
\hline $140^{\circ} \mathrm{W}$ & 16 & $\begin{array}{l}\text { Median } \\
\text { Range }\end{array}$ & $\begin{array}{l}0.54 \\
-1.15 \text { to } 1.00\end{array}$ & $\begin{array}{l}1.73 \\
0.38 \text { to } 10.07\end{array}$ & $\begin{array}{l}-4.47 \\
-26.13 \text { to } 2.32\end{array}$ & $\begin{array}{l}-0.73 \\
-7.24 \text { to } 21.39\end{array}$ & $\begin{array}{l}589.91 \\
286.89-1392.02\end{array}$ \\
\hline $155^{\circ} \mathrm{W}$ & 15 & $\begin{array}{l}\text { Median } \\
\text { Range }\end{array}$ & $\begin{array}{l}0.39 \\
0 \text { to } 1.57\end{array}$ & $\begin{array}{l}1.15 \\
0.28 \text { to } 2.66\end{array}$ & $\begin{array}{l}0.51 \\
-12.42 \text { to } 6.81\end{array}$ & $\begin{array}{l}-2.76 \\
-18.45 \text { to } 0.19\end{array}$ & $\begin{array}{l}498.58 \\
183.84-844.39\end{array}$ \\
\hline $170^{\circ} \mathrm{W}$ & 15 & $\begin{array}{l}\text { Median } \\
\text { Range }\end{array}$ & $\begin{array}{l}0.53 \\
0.26 \text { to } 1.01\end{array}$ & $\begin{array}{l}2.10 \\
0.87 \text { to } 15.63\end{array}$ & $\begin{array}{l}-1.59 \\
-13.62 \text { to } 12.85\end{array}$ & $\begin{array}{l}-1.57 \\
-7.76 \text { to } 9.47\end{array}$ & $\begin{array}{l}434.71 \\
196.05-1072.18\end{array}$ \\
\hline $180^{\circ}$ & 2 & $\begin{array}{l}\text { Median } \\
\text { Range }\end{array}$ & $\begin{array}{l}0.52 \\
0.43 \text { to } 0.60\end{array}$ & $\begin{array}{l}2.04 \\
1.82 \text { to } 2.25\end{array}$ & $\begin{array}{l}-6.25 \\
-6.56 \text { to }-5.94\end{array}$ & $\begin{array}{l}-0.57 \\
-2.02 \text { to } 0.88\end{array}$ & $\begin{array}{l}536.83 \\
492.53-581.13\end{array}$ \\
\hline Pooled & 48 & $\begin{array}{l}\text { Median } \\
\text { Range }\end{array}$ & $\begin{array}{l}0.52 \\
-1.15 \text { to } 1.57\end{array}$ & $\begin{array}{l}1.75 \\
0.28 \text { to } 15.63\end{array}$ & $\begin{array}{l}-2.01 \\
-26.13 \text { to } 12.85\end{array}$ & $\begin{array}{l}-1.41 \\
-18.45 \text { to } 21.39\end{array}$ & $\begin{array}{l}496.66 \\
183.84-1392.02\end{array}$ \\
\hline
\end{tabular}




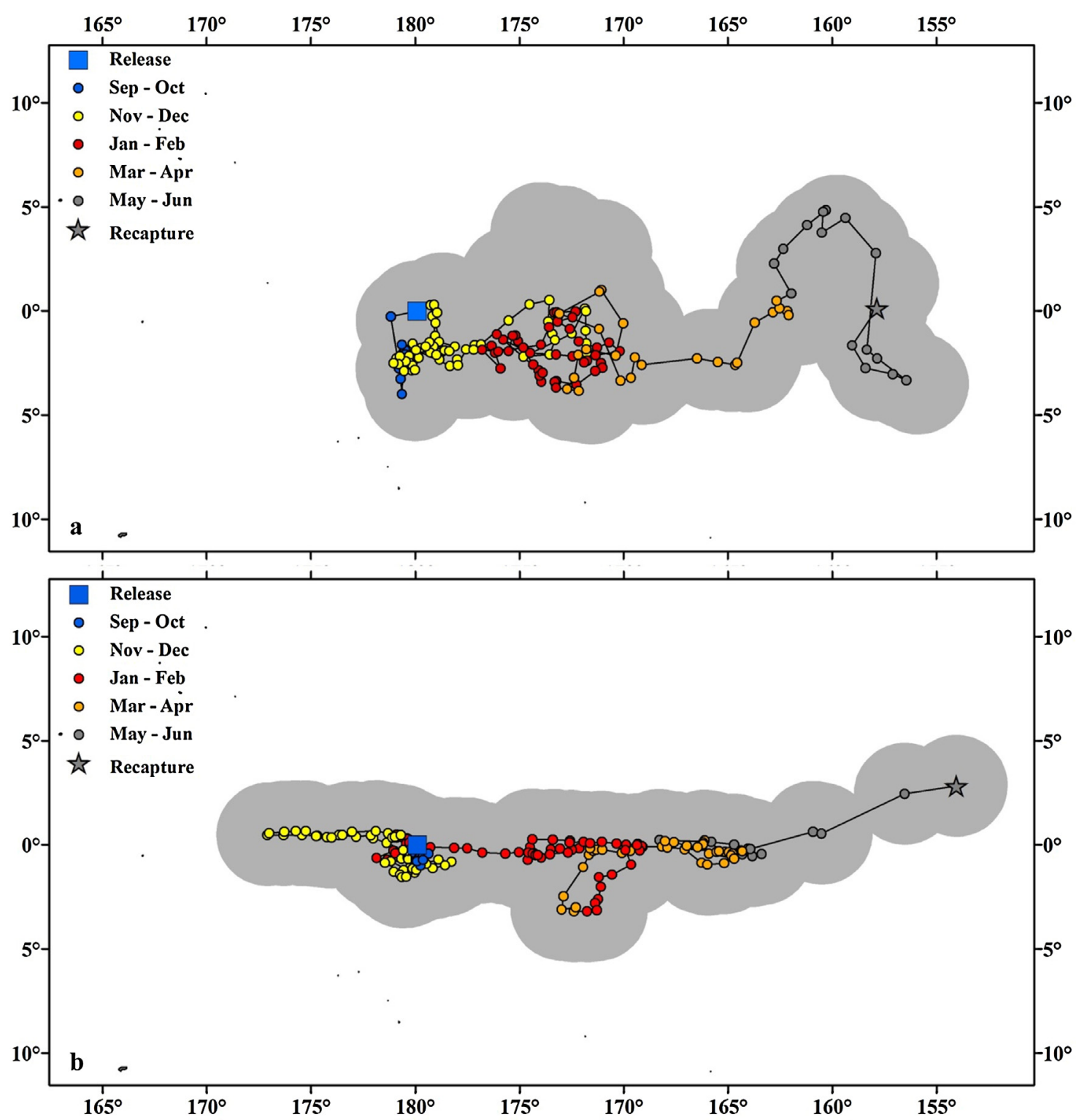

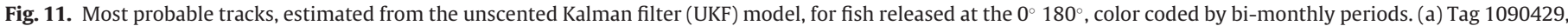

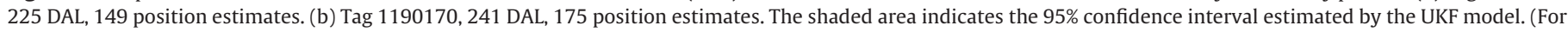
interpretation of the references to color in figure legend, the reader is referred to the web version of the article.)

$29 \%$ in a westward direction. The distribution of recaptures shows constrained latitudinal dispersion between about $10^{\circ} \mathrm{N}$ to $10^{\circ} \mathrm{S}$, with a few recaptures as far south as $18.5^{\circ} \mathrm{S}$ and one fish as far north as $27^{\circ} \mathrm{N}$. The western extent of recaptures was about $142.5^{\circ}$ E. On the eastern extent, most recaptures were west of $90^{\circ} \mathrm{W}$, but there were 19 between $90^{\circ} \mathrm{W}$ and $77.5^{\circ} \mathrm{W}$.

Results of bigeye tuna tagging experiments, using DTs, in the equatorial EPO at about $95^{\circ} \mathrm{W}$ (Schaefer and Fuller, 2009), demonstrated that for 6692 fish with $\geq 30 \mathrm{DAL}$, the median LD was $259 \mathrm{M}$ and $95 \%$ of the fish were recaptured within $1016 \mathrm{M}$ of their release locations. $80 \%$ of the LDs were in a westward direction, and $20 \%$ in an eastward direction. The distribution of recaptures shows constrained latitudinal dispersion between $10^{\circ} \mathrm{N}$ and $10^{\circ} \mathrm{S}$. The eastern extent of recaptures was about $80^{\circ} \mathrm{W}$. On the western extent, most recaptures were east of $130^{\circ} \mathrm{W}$, but there were 74 between $130^{\circ}$ $\mathrm{W}$ and $151^{\circ} \mathrm{W}$, with one as far west as $158^{\circ} \mathrm{W}$.

Results of bigeye tuna tagging experiments, using DTs, in the equatorial WPO between about $10^{\circ} \mathrm{N}$ to $10^{\circ} \mathrm{S}$ and $125^{\circ} \mathrm{E}$ to $175^{\circ}$ E, demonstrated that for 456 fish with $\geq 30$ DAL, the median LD was $276 \mathrm{M}$ and $95 \%$ of the fish were recaptured within $1054 \mathrm{M}$ of their release locations. 56\% of the LDs were in an eastward direction, and $44 \%$ westward direction. The distribution of recaptures shows constrained latitudinal dispersion between $10^{\circ} \mathrm{N}$ and $10^{\circ} \mathrm{S}$. The western extent of recaptures was about $125^{\circ} \mathrm{E}$, with most of them occurring between $140^{\circ} \mathrm{E}$ and $175^{\circ} \mathrm{E}$. The eastern extent of recaptures was about $150^{\circ} \mathrm{W}$ (SPC, unpublished data).

The release and recovery positions from the tagging experiments in the CPO, EPO, and WPO, described above and illustrated in Fig. 13, can be utilized to estimate mixing rates across putative stock boundaries. For the 456 fish, with $\geq 30 \mathrm{DAL}$, recovered from releases west of $180^{\circ}$ in the WPO, $20(4.4 \%)$ and $0(0.0 \%)$ were recovered east of $180^{\circ}$ and $120^{\circ} \mathrm{W}$, respectively. For 6692 fish with $\geq 30 \mathrm{DAL}$, recovered from releases east of $120^{\circ} \mathrm{W}$ in the EPO, 159 (2.4\%) and $0(0.0 \%)$ were recovered west of $120^{\circ} \mathrm{W}$ and $180^{\circ} \mathrm{W}$, respectively. For $5572 \mathrm{fish}, \geq 30 \mathrm{DAL}$, recovered from releases between $120^{\circ} \mathrm{W}$ and $170^{\circ} \mathrm{W}$ in the $\mathrm{CPO}$, thus excluding recoveries from releases at the $180^{\circ}$ meridian due to the close proximity to the putative stock boundary, $1538(27.6 \%)$ and $418(7.5 \%)$ were recovered east of $120^{\circ}$ 


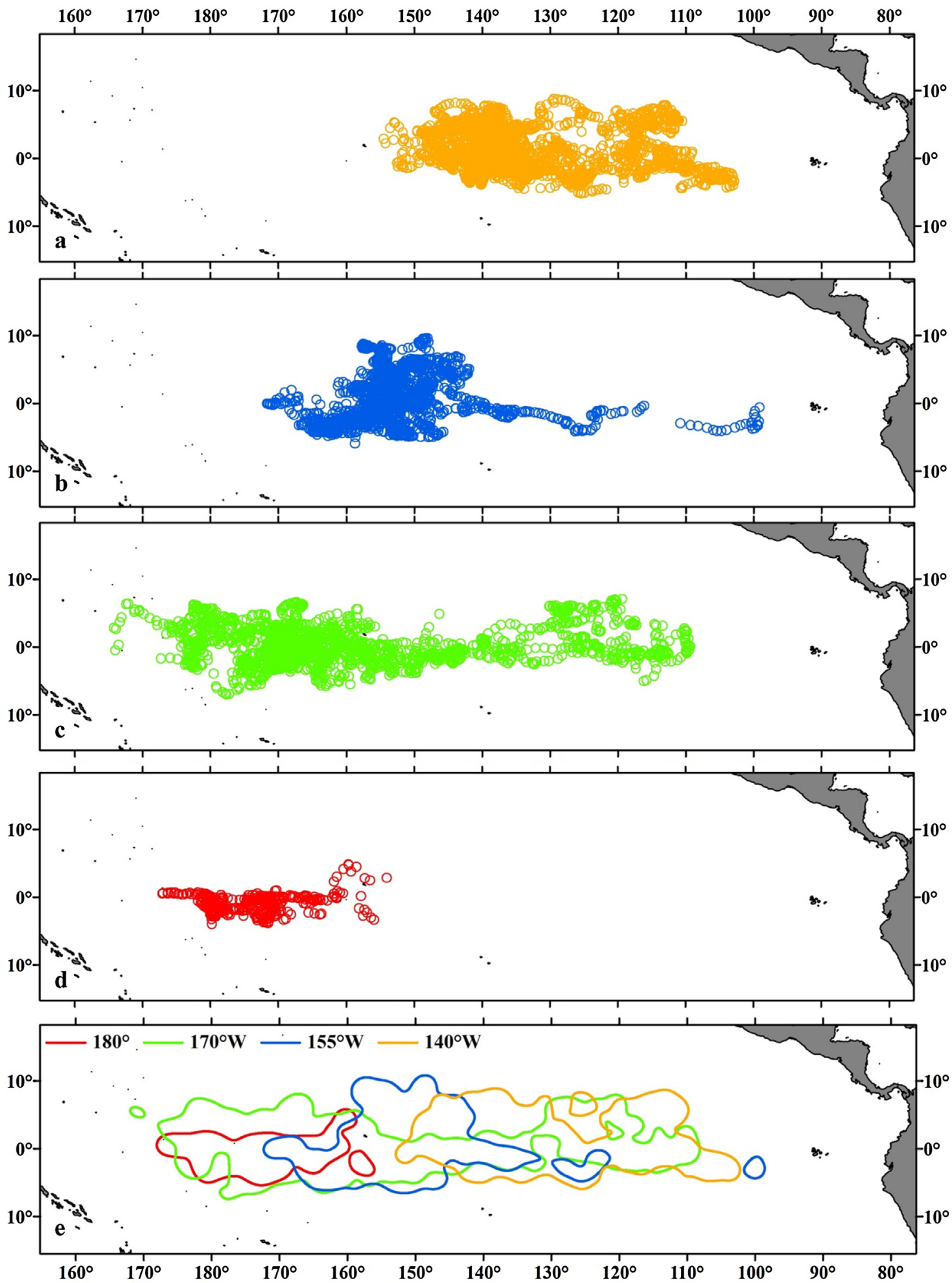

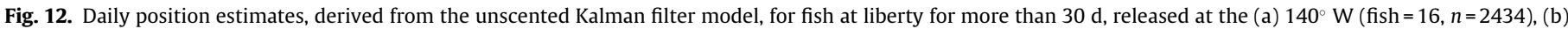

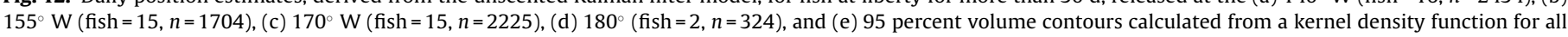
positions included with a $1^{\circ}$ search radius and a $0.01^{\circ}$ output cell size.

$\mathrm{W}$ and west of $180^{\circ} \mathrm{W}$, respectively. These results indicate that bigeye tuna exhibit higher levels of viscosity and fidelity in the eastern and western regions of the equatorial Pacific, and a pattern of predominantly eastward extensive dispersion in the central region of the equatorial Pacific.

Further results from the bigeye tuna tagging experiments with DTs in the equatorial CPO, indicate that $95 \%$ of the LDs extended to about $2700 \mathrm{M}$ from releases along the $140^{\circ} \mathrm{W}$ and $155^{\circ} \mathrm{W}$ meridians, but much further to about 4200 and $4000 \mathrm{M}$, for releases along the $170^{\circ} \mathrm{W}$ and $180^{\circ}$ meridians, respectively. Although about $76 \%$ of the LDs from releases along the $140^{\circ} \mathrm{W}$ were in an eastward direction and $24 \%$ westward direction, for releases along the $155^{\circ}$ $\mathrm{W}, 170^{\circ} \mathrm{W}$, and $180^{\circ}$ meridians, about $65-70 \%$ of the LDs were in an eastward direction, and 30-35\% westward direction. For the DT 


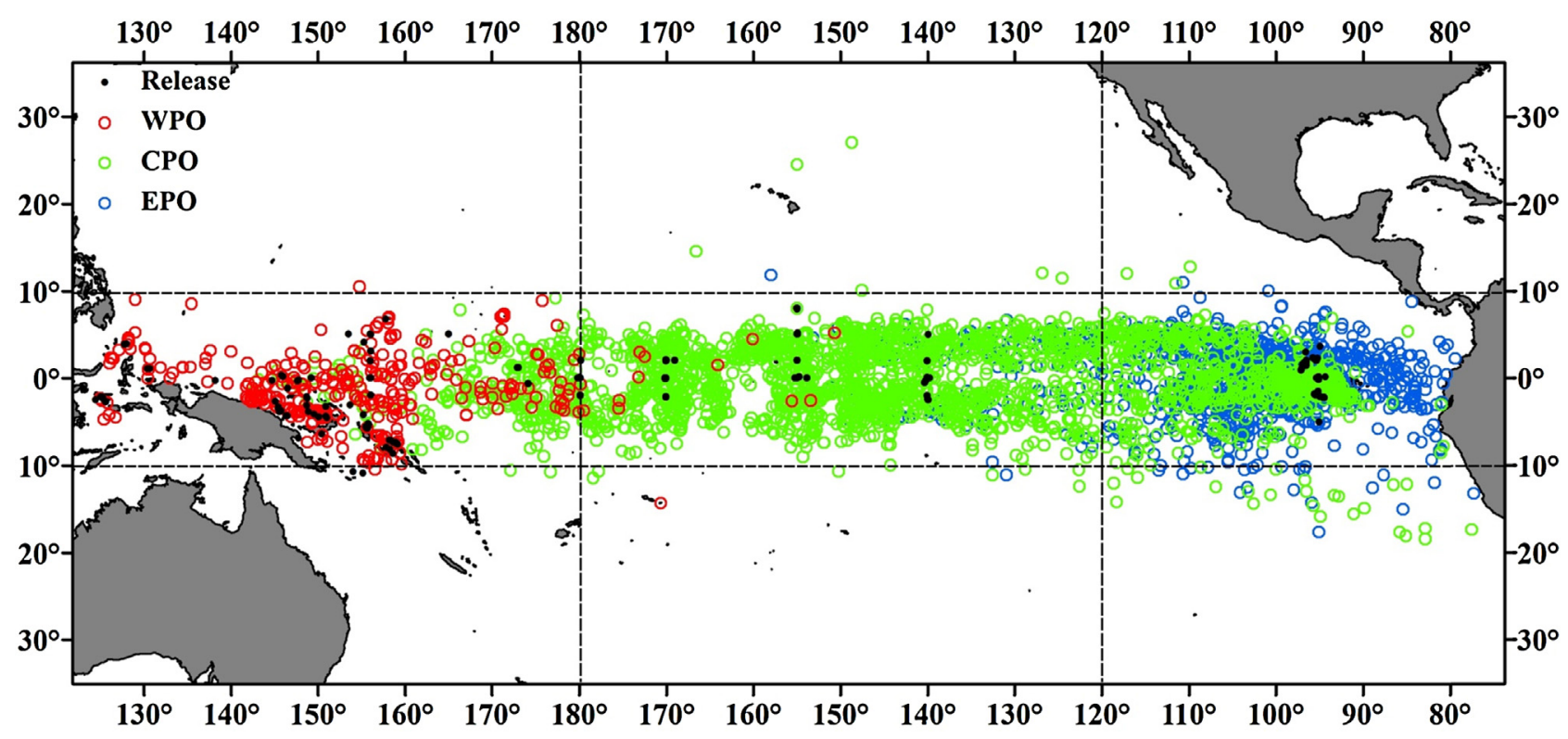

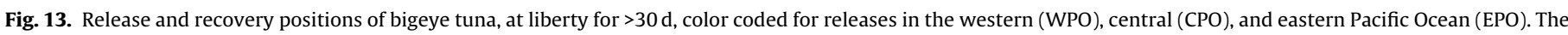

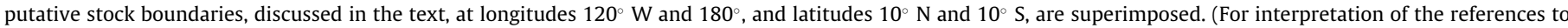
color in figure legend, the reader is referred to the web version of the article.)

data, from releases at each of the four meridians in the equatorial $\mathrm{CPO}$, there was a significant positive correlation between $\mathrm{LD}$ and DAL. For the DT data from the $140^{\circ} \mathrm{W}$ meridian, there was also a significant positive correlation between $L D$ and fish length, but for the DT data from the $155^{\circ} \mathrm{W}, 170^{\circ} \mathrm{W}$, and $180^{\circ}$ meridians there was a significant negative correlation. The length ranges of bigeye tuna released along these four meridians are quite restricted, with most fish $<70 \mathrm{~cm}$, and thus these data appear inadequate to provide a clear pattern regarding relationships between LDs, DAL, and fish length.

For the bigeye tuna tagging experiments, with DTs, in the equatorial EPO, there was also a significant positive correlation between greater LDs and DAL. A pattern was also apparent for LDs by lengths at release, and DAL, since fish $>80 \mathrm{~cm}$ and $>365$ DAL, showed significantly greater LDs than fish $<80 \mathrm{~cm}$, and those $>80 \mathrm{~cm}<365$ DAL (Schaefer and Fuller, 2009). Results from bigeye tuna tagging experiments, with DTs, in the equatorial WPO, indicate LDs varied significantly with release location, DAL, and length at release (Hoyle et al., 2013). A nonlinear relationship was reported between LDs and DAL, showing an increase in LDs to about 9 months at liberty, then a decline to about 18 months, followed by an increase. These analyses also showed a negative relationship between length at release and LDs, over a length range from about 40 to $80 \mathrm{~cm}$.

\subsection{Archival tags}

Analyses of the data from the 48 ATs, utilizing the UKFsst, made possible the reconstruction of MPTs of individual fish, estimation of $95 \%$ percent volume contours for all positions along MPTs by release longitudes calculated from a kernel density function, and estimation of movement parameters by release longitudes, and pooled data. It is evident from these analyses that there is considerable variation in movement among individuals from within release longitudes, and among individuals from among release longitudes. The movement patterns for the releases along the $155^{\circ} \mathrm{W}$ meridian illustrate fairly strong regional fidelity to release location, but those for the releases along the $140^{\circ} \mathrm{W}$ and $170^{\circ} \mathrm{W}$ meridian, show less regional fidelity, but more eastward movements. In comparison, for the 98 ATs recovered from bigeye tuna $\geq 30$ DAL from releases at $95^{\circ} \mathrm{W}$ in the equatorial EPO, processed with the UKFsst, the predominant movement patterns and spatial distributions of estimated positions indicate strong regional fidelity, with restricted westward movements (Schaefer and Fuller, 2009). The 95\% volume contours for all estimated positions from AT deployments along the $140^{\circ} \mathrm{W}, 155^{\circ} \mathrm{W}$, and $170^{\circ} \mathrm{W}$ meridians, range from about 1.6 to 2.6 million $\mathrm{M}^{2}$, whereas for the AT deployments along the $95^{\circ}$ $\mathrm{W}$ meridian the $95 \%$ volume contour for all estimated positions is only about 0.7 million $\mathrm{M}^{2}$ (Schaefer and Fuller, 2009). The median movement parameters from the UKFsst, by release location, and for the pooled data, from this study (Table 7), compared to the lower values derived for bigeye tuna from the equatorial EPO of $1.25 \mathrm{M} / \mathrm{d}$ for directed eastward movement $(u), 0.35 \mathrm{M} / \mathrm{d}$ for directed northward movement $(v)$, and $465 \mathrm{M}^{2} / \mathrm{d}$ for dispersion $(D)$ (Schaefer and Fuller, 2009), describe the differences in bigeye tuna MPTs obtained from the equatorial CPO and EPO AT deployments.

The AT data from this tagging study, along with that from the equatorial EPO (Schaefer and Fuller, 2009), appear to indicate that there are three general types of bigeye tuna movement: (1) fish that are residents within an area (reside at $<1000 \mathrm{M}$ of release location), (2) fish that are residents, yet undertake cyclical excursions outside the area, and (3) fish that are nomadic and do not demonstrate type 1 or type 2 movement patterns. Type 1 and 2 movement patterns, we refer to as demonstrating regional fidelity to an area of release. In some instances, a type- 3 movement pattern may occur because the fish were not at liberty for sufficient time to demonstrate a type2 movement pattern. An example of that, is the type- 2 movement pattern described by Schaefer and Fuller (2010), derived from a bigeye tuna four-year AT deployment, in which the fish demonstrated two seasonal cyclical migrations during the latter two years. The AT data from the present study, for 48 bigeye tuna, demonstrated that 30 (62.5\%) fish exhibited a type-1 movement pattern, 4 (8.3\%) fish exhibited a type-2 movement pattern, and 14 (29.2\%) fish exhibited a type-3 movement pattern (Table 6).

For comparing AT and DT LDs, only recoveries with $>30 \mathrm{DAL}$ were utilized and DT data was truncated so that DAL did not exceed that of the ATs. Mann-Whitney tests were performed on the LDs between ATs and DTs, by longitude of release, indicating no significant differences for fish released along the $170^{\circ} \mathrm{W}$ and $155^{\circ} \mathrm{W}$ meridians ( $P=0.151$ and $P=0.160$, respectively). However, for fish released along the $140^{\circ} \mathrm{W}$ meridian there is a significant difference 
$(P=0.026)$, with greater LDs exhibited for the fish with DTs. This difference appears to be largely driven by the 90-179 DAL group $(P=0.049)$, as the $30-89$ and $180-365$ DAL groups show no significant difference in LDs ( $P=0.680$ and $P=0.535$ respectively) and the $>365$ DAL group has only one AT. With only two ATs recovered from fish released along the $180^{\circ} \mathrm{W}$ no statistical tests were performed to compare those LDs with the DT LDs.

\subsection{Movements, dispersion, stock structure, and mixing in the Pacific}

The predominantly eastward extensive dispersion of bigeye tuna tagged with DTs and ATs in the present study, is in contrast to the results from the tagging along the $95^{\circ} \mathrm{W}$ in the equatorial EPO, which demonstrated strong regional fidelity and limited westward dispersion (Schaefer and Fuller, 2009). Habitat requirements for the residence of bigeye tuna undoubtedly include high food concentrations, and suitable environmental conditions for spawning. Considering that all of the fish released and recaptured in this study were smaller than the minimum size at sexual maturity (about $100 \mathrm{~cm}$ ) and that bigeye tuna spawning has been reported to take place in the CPO and EPO between about $15^{\circ} \mathrm{N}$ and $15^{\circ} \mathrm{S}$ (Schaefer et al., 2005), searching for suitable spawning habitat does not appear to be a basis for the predominantly eastward extensive dispersion. Regarding the distribution of high food concentrations, mesopelagic fish, cephalopods, and crustaceans are the major components in the diet of bigeye tuna in the equatorial CPO and EPO (King and Ikehara, 1956; Blunt, 1960). A plausible reason for the relatively high abundance of bigeye tuna across the equatorial Pacific relates to the equatorial current system (Tomczak and Godfrey, 2003; Fiedler and Talley, 2006), which is the mechanism for highly productive equatorial upwelling, supporting high concentrations of mesopelagic fish, cephalopods, and crustaceans, which are the primary components of the vertically migrating deep-scattering layer, observed throughout the equatorial Pacific (Longhurst, 1976; Tont, 1976).

In the area of the equatorial EPO between about $90^{\circ} \mathrm{W}$ and $115^{\circ}$ $\mathrm{W}$, where bigeye tuna exhibit strong regional fidelity, it appears that high concentration of food is an important environmental factor leading to their residence and retention in that area (Schaefer and Fuller, 2009). This is the result of the cooler waters of the Peru Current flowing northward and then flowing westward as the equatorial cold tongue of the south equatorial current (SEC) (Fiedler and Tally, 2006). Advection of the cooler water from the Peru Current and equatorial upwelling generate high nutrient concentrations in this specific region, leading to high concentrations of surface chlorophyll and phytoplankton biomass throughout the year (Pennington et al., 2006) and high zooplankton abundance (Fernandez-Alamo and Farber-Lorda, 2006). Those in turn support the high concentrations of forage species in the diet of bigeye tuna in the equatorial EPO.

The equatorial current system is very dynamic, with horizontal and vertical structure, and contains elements of both westward and eastward flow (Tomczak and Godfrey, 2003). Below the winddriven westward-flowing SEC, which reaches speeds up to about $0.6 \mathrm{~ms}^{-1}$, is the swift subsurface eastward-flowing equatorial undercurrent (EUC), extending along the equator between about $2^{\circ} \mathrm{N}$ and $2^{\circ} \mathrm{S}$, with typical speeds of $1.5 \mathrm{~m} \mathrm{~s}^{-1}$. The EUC has a thickness of about $200 \mathrm{~m}$, and the core is found at $200 \mathrm{~m}$ depth in the west, and rises to $40 \mathrm{~m}$ or less in the east. The westward-flowing SEC and eastward-flowing EUC appear to have little influence on movements and dispersion of bigeye tuna from releases along the $95^{\circ} \mathrm{W}$ meridian. However, a plausible cause for the predominantly eastward extensive dispersion of bigeye tuna from releases in the equatorial CPO is the influence of the strong eastwardflowing EUC, in combination with bigeye tuna searching for higher concentrations of prey resources, so as to maximize foraging success in a more productive area. Bigeye tuna have been shown, from archival tag data analyses, to spend a high proportion of their days at depths within the core of the EUC in the equatorial CPO and EPO (Schaefer and Fuller, 2010).

There appears to be considerable latitudinal separation of the stocks of bigeye tuna in the Pacific, with those found in the equatorial region demonstrating very low levels of mixing with those found at higher northern and southern latitudes. Results from the current study, include the recaptures of two bigeye tuna by longline vessels at $24^{\circ} 30^{\prime} \mathrm{N} 155^{\circ} \mathrm{W}$ and $27^{\circ} 03^{\prime} \mathrm{N} 148^{\circ} 41^{\prime} \mathrm{W}$, north to north-east of the main Hawaiian Islands, and a few recaptures by purse-seine vessels as far south as $19^{\circ} \mathrm{S}$, off northern Chile. There were also two bigeye tuna released in the equatorial WPO at $1^{\circ}$ $\mathrm{S} 173^{\circ} \mathrm{E}$ and $2^{\circ} \mathrm{S} 180^{\circ}$, recaptured by longline vessels, just south of Hawaii, at $21^{\circ} \mathrm{N} 156^{\circ} \mathrm{W}$ and $20^{\circ} \mathrm{N} 160^{\circ} \mathrm{W}$ (Hampton et al., 1998). However, bigeye tuna tagging studies in Hawaii using DTs (Itano and Holland, 2000) and pop-up satellite archival tags (PSATs) (Howell et al., 2010) did not result in any recaptures in the equatorial Pacific, or produce any MPTs inferring movements to that area. There is a record of one bigeye tuna released in the NE Pacific at $34^{\circ}$ $\mathrm{N} 133^{\circ} \mathrm{W}$, which was recaptured in the equatorial EPO at $2^{\circ} \mathrm{N}$ and $99^{\circ} \mathrm{W}$, but there are no reported recaptures north of $12^{\circ} \mathrm{N}$ of bigeye tuna from tagging studies in the equatorial EPO (Schaefer and Fuller, 2009). Results of bigeye tuna tagging studies using DTs in waters of Japan indicate that most LDs greater than $1000 \mathrm{M}$ have been northeastward from release locations (Matsumoto et al., 2007), but one bigeye tuna was recaptured in the equatorial WPO at about $8^{\circ} \mathrm{N}$ and $151^{\circ} \mathrm{E}$, after about five years at liberty (Matsumoto et al., 2013). Bigeye tuna tagging studies in the Coral Sea with DTs demonstrated fairly restricted movements and a high degree of residency, but also showed several LDs to equatorial waters of the WPO, CPO, and even the EPO (Hampton and Gunn, 1998). Deployments of ATs in bigeye tuna in the Coral Sea demonstrated pronounced residency within the Coral Sea, with just 2 of 14 fish demonstrating some east-west cyclical movements (Clear et al., 2005).

The predominantly eastward extensive dispersion of bigeye tuna observed in this study appears valid, since an evaluation of the purse-seine effort distribution across the Pacific, between $10^{\circ}$ $\mathrm{N}$ and $10^{\circ} \mathrm{S}$, during 2008-2012 indicates the movements observed from the tagging data, are unlikely to be a product of the effort distribution. It could be argued, however, that the results demonstrating restricted latitudinal dispersion of bigeye tuna, are biased by the restricted latitudinal distribution of purse-seine fishing effort focused in the equatorial region (Fig. 1), in conjunction with the low probability of recaptures of tagged bigeye tuna to the north and south of this region from longline fisheries. We recognize that the movement patterns observed are representative only for the sizes of fish in this study, and the timing and locations of the tagging events. Movement patterns for much larger and/or older bigeye tuna, or fish tagged and released during other years, may differ considerably due to ontogenetic changes in behavior, or responses to large-scale environmental conditions that impact SSTs, currents, vertical structure, and productivity. The period of the tagging 2008-2012, was dominated by La Nina and ENSO-neutral conditions, and different movement patterns may occur during El Nino dominated periods.

Previous to this study, interpretations of the dispersion and mixing of bigeye tuna across the equatorial Pacific, were based on a few tagging experiments conducted near the margins of the Pacific, and at great distances from the $150^{\circ} \mathrm{W}$ meridian, limited numbers of bigeye tuna releases, relatively short times at liberty, and relatively small sizes of fish at release and recapture. Inferences made regarding apparent stock structure and the very limited mixing of bigeye tuna being exploited in the eastern and western equatorial Pacific, were apparently premature. 
The results of this study, and the tagging studies for bigeye tuna in the equatorial EPO and WPO, indicate that three putative stocks (eastern, central, and western) occur across the equatorial Pacific Ocean, between $10^{\circ} \mathrm{N}$ and $10^{\circ} \mathrm{S}$, with stock boundaries at about $120^{\circ} \mathrm{W}$ and $180^{\circ}$. Six additional putative stocks should be considered to occur in the Pacific; three northward and three southward of those in the equatorial Pacific. The existence of bigeye tuna stocks in the equatorial region, and at higher northern and southern latitudes of the Pacific, is likely the result of bigeye tuna having celestial and geomagnetic compasses (Gould, 1998, 2008), the ability to navigate (Walker, 1984), and the intrinsic motivation to remain within a familiar and suitable habitat for feeding and reproduction. The westward and eastward expansions of purse-seine fishing effort, into the previously lightly exploited equatorial CPO (Fig. 1), for targeting tuna aggregations associated with DFADs, necessitates a better understanding of bigeye tuna stock structure and mixing, and evaluations of appropriate spatial structure to be used in bigeye tuna stock assessments. It is also essential to conduct research on important life history characteristics including growth, reproduction, and mortality so as to estimate those parameters within the strata to be used in spatially structured assessments, considering the geographic variation in life history characteristics that no doubt, occur across the equatorial Pacific (Schaefer et al., 2005; Schaefer and Fuller, 2006). Currently, much of this scientific information is lacking, but if ongoing bigeye tuna tagging studies and investigations of life history continue to be supported, these essential parameters could be estimated, leading to improved Pacific-wide bigeye tuna stock assessments.

\section{Acknowledgements}

This research was made possible through financial support for the Pacific Tuna Tagging Programme provided by the PNG National Fisheries Authority, New Zealand Aid Agency, the Government of the Republic of Korea, Australian Centre for International Agricultural Research, European Community 8th, 9th, and 10th European Development Funds, the French Pacific Fund, the Government of Taiwan, Heinz Australia and the Global Environment Facility. We are grateful to NOAA for the existence and maintenance of the TAO array, without which these tagging experiments could not have been conducted. We are thankful to Captains Joe Dettling, Tim Jones, and Etimoni Palu for their efforts during tagging cruises aboard their vessels. We are indebted to vessel owners, captains, fishermen, unloaders, and industry representatives for returning recovered tags. Thanks also to all tag recovery officers and field office staff for their hard work and continued efforts in recovering tags and recapture information. We also wish to thank Bill Bayliff, Rick Deriso, Andre Punt, and two anonymous reviewers for constructive comments on drafts of the manuscript.

\section{References}

Aires-da-Silva, A., Maunder, M.N., 2014. Status of bigeye tuna in the eastern Pacific Ocean in 2012 and outlook for the future. Inter-Am. Trop. Tuna Comm. Stock Assess. Rep. 14, 31-185 https://www.iattc.org/PDFFiles2/ StockAssessmentReports/SAR-14-BET-ENG.pdf

Aires-da-Silva, A., Maunder, M.N., Schaefer, K.M., Fuller, D.W., 2014. Improved growth estimates from integrated analysis of direct aging and tag recapture data: an illustration with bigeye tuna (Thunnus obesus) of the eastern Pacific Ocean with implications for management. Fish. Res. (in press).

Anonymous, 2011. WCPFC-IATTC Overlap Area. Western and Central Pacific Fisheries Commission, Document Number WCPFC8-2011/41 Rev 1, 7 pp. http://www.wcpfc.int/system/files/WCPFC9-2012-IP01-WCPFC-IATTC-overlap -area-WCPFC8-paper.pdf

Anonymous, 2013. Tunas and billfishes in the eastern Pacific Ocean in 2012. InterAm. Trop. Tuna Comm. Fish. Status Rep. 11, 171 pp. https://www.iattc.org/ PDFFiles2/FisheryStatusReports/Fishery-Status-Report-11ENG.pdf

Bayliff, W.H., 1993. An indexed bibliography of papers on tagging of tunas and billfishes. Inter-Am. Trop. Tuna Comm. Spec. Rep. 8, 91 pp. https://www.iattc.org/PDFFiles2/SpecialReports/SpecialReport8.pdf
Bayliff, W.H., Holland, K.N., 1986. Materials and methods for tagging tunas and billfishes, recovering the tags, and handling the recapture data. FAO Fish. Tech. Pap. $279,36$.

Block, B.A., Teo, S.L.H., Walli, A., Boustany, A., Stokesbury, M.J.W., Farwell, C.J., Weng K.C., Dewar, H., Williams, T.D., 2005. Electronic tagging and population structure of Atlantic Bluefin tuna. Nature 434, 1121-1127.

Blunt Jr., C.E., 1960. Observations on the food habits of longline caught bigeye tuna and yellowfin tuna from the tropical eastern Pacific 1955-1956. Calif. Fish Game 46, 69-80.

Boustany, A.M., Matteson, R., Castleton, M., Farwell, C., Block, B.A., 2010. Movements of Pacific bluefin tuna (Thunnus orientalis) in the eastern North Pacific revealed with archival tags. Prog. Ocean. 86, 94-104.

Clear, N.P., Evans, K., Gunn, J.S., Bestley, S., Hartmann, K., Patterson, T., 2005. Movement of bigeye tuna (Thunnus obesus) determined from archival tag light-levels and sea surface temperatures. In: Migration and Habitat Preferences of Big eye tuna, Thunnus obesus, on the East Coast of Australia. CSIRO Report FRPC 1999/109., pp. 19-46.

Davies, N., Hoyle, S., Harley, S., Langley, A., Kleiber, P., Hampton, J., 2011 Stock Assessment of Bigeye Tuna in the Western and Central Pacific Ocean. Western and Central Pacific Fisheries Commission, Document Number WCPFC-SC7-2011/SA-WP-02, 133 pp. http://www.wcpfc.int/system/ files/SC7-SA-WP-02\%20\%5BBET\%20Assessment\%5D.pdf

Ekstrom, P.A., 2004. An advance in geolocation by light. In: Naito, Y. (Ed.), Memoirs of the National Institute of Polar Research, Special Issue. National Institute of Polar Research, Tokyo, pp. 210-226.

Fernandez-Alamo, M.A., Farber-Lorda, J., 2006. Zooplankton and oceanography of the eastern tropical Pacific: a review. Prog. Ocean. 69, 318-359.

Fiedler, P.C., Talley, L.D., 2006. Hydrography of the eastern tropical Pacific: a review. Prog. Ocean. 69, 143-180.

Fonteneau, A., Pallares, P., Pianet, R., 2000. A worldwide review of purseseine fisheries on FADs. In: LeGall, J.-Y., Cayre, P., Taquet, M. (Eds.), Peche thoniere et dispositifs de concentration de poisons. Actes Colloques-IFREMER, pp. 15-35.

Fonteneau, A., Chassot, E., Bodin, N., 2013. Global spatio-temporal patterns in tropical tuna purse seine fisheries on drifting fish aggregating devices (DFADs): taking a historical perspective to inform current challenges. Aquat. Living Resour. 26 37-48.

Gould, J.L., 1998. Sensory bases of navigation. Curr. Biol. 8, R731-R738.

Gould, J.L., 2008. Animal navigation: the evolution of magnetic orientation. Curr Biol. 18, R482-R484.

Hampton, J., Gunn, J., 1998. Exploitation and movements of yellowfin tuna (Thunnus albacares) and bigeye tuna (T. obesus) tagged in the north-western Coral Sea. Mar. Freshw. Res. 49, 475-489.

Hampton, J., Bigelow, K., Labelle, M., 1998. A summary of current information on the biology, fisheries and stock assessment of bigeye tuna (Thunnus obesus) in the Pacific Ocean, with recommendations for data requirements and future research. Secretariat of the Pacific Community, Oceanic Fisheries Programme, Tech. Rep. 36, 46 pp. http://www.spc.int/DigitalLibrary/ Doc/FAME/Reports/Hampton_98_OFPTRpt_36.pdf

Hampton, J., Williams, P., 2005. A description of tag-recapture data for bigeye tuna (Thunnus obesus) in the western and central Pacific Ocean. Inter. Comm. Conser. Atlan. Tunas Coll. Vol. Sci. Pap. 57, 85-93.

Howell, E.A., Hawn, D.R., Polovina, J.J., 2010. Spatiotemporal variability in bigeye tuna (Thunnus obesus) dive behavior in the central North Pacific Ocean. Prog. Ocean. 86, 81-93

Hoyle, S.D., Kolody, D.S., Nicole, S., 2013. Analyses of Tagging Data for Tropica Tunas, with Implications for the Structure of WCPO Bigeye Tuna Stock Assessments. Western and Central Pacific Fisheries Commission, Document Number WCPFC-SC9-2013/SA-IP-06, 67 pp. https://wcpfc.int/system/files/SA-IP-06\%5BTagging-data-and-spatial-structure-WCPO-assessmentsJuly26\%5D.pdf

Hunter, J.R., Argue, A.W., Bayliff, W.H., Dizon, A.E., Fonteneau, A., Goodman, D., Seckel, G.R., 1986. The dynamics of tuna movements: an evaluation of past and future research. FAO Fish. Tech. Pap. 277, 78.

Itano, D.G., Holland, K.N., 2000. Movement and vulnerability of bigeye tuna (Thunnus obesus) and yellowfin tuna (Thunnus albacares) in relation to FADs and natural aggregation points. Aquat. Living Resour. 13, 213-223.

King, J.E., Ikehara, I.I., 1956. Comparative study of food of bigeye tuna and yellowfin tuna in the central Pacific. U.S. Fish Wildl. Serv Fish. Bull. 57, 61-85.

Lam, C.H., Nielsen, A., Sibert, J., 2008. Improving light and temperature based geolocation by unscented Kalman filtering. Fish. Res. 91, 15-25.

Leroy, B., Nicol, S., Lewis, A., Hampton, J., Kolody, D., Caillot, S., Hoyle, S., 2013. Lessons learned from implementing three, large-scale tuna tagging programmes in the western and central Pacific Ocean. Fish. Res. (in press).

Longhurst, A.R., 1976. Vertical migration. In: Cushing, D.H., Walsh, J.J. (Eds.), The Ecology of the Seas. Blackwell, London, pp. 116-137.

Matsumoto, T., Semba, Y., Okamoto, H., Sakaki, J., Kondo, S., Okuhara, M., Ohta I., Mizoguchi, M., 2007. Report of the Ongoing Tagging Project on Tropical Tunas in the Southern Part of Japan. Western and Central Pacific Fisheries Commission, Document Number WCPFC-SC3-BI SWG/WP-5, 14 pp. https://wcpfc.int/system/files/BI-WP-5\%20document.pdf

Matsumoto, T., Kitagawa, T., Kimura, S., 2013. Vertical behavior of bigeye tuna (Thunnus obesus) in the northwestern Pacific Ocean based on archival tag data. Fish. Oceanogr. 22, 234-246.

Miyabe, N., Bayliff, W.H., 1998. A review of information on the biology, fisheries, and stock assessment of bigeye tuna, Thunnus obsesus, in the Pacific Ocean. Inter-Am. Trop. Tuna Comm. Spec. Rep. 9, 129-170. 
Miyake, M.P., Miyabe, N., Nakano, H., 2004. Historical trends of tuna catches in the world. FAO Fish. Tech. Pap. 467, 74 pp.

Nielsen, A., Bigelow, K.A., Musyl, M.K., Sibert, J.R., 2006. Improving light-based geolocation by including sea surface temperature. Fish. Oceanogr. 15, 314-325.

Pennington, J.T., Mahoney, K.L., Kuwahara, V.S., Kolber, D.D., Calienes, R., Chavez, F.P., 2006. Primary production in the eastern tropical Pacific: a review. Prog. Ocean. 69, 285-317

Reynolds, R.W., Smith, T.M., 1994. Improved global sea surface temperature analyses using optimal interpolation. J. Clim. 7, 929-948.

Schaefer, K.M., Fuller, D.W., 2002. Movements, behavior, and habitat selection of bigeye tuna (Thunnus obesus) in the eastern equatorial Pacific, ascertained through archival tags. Fish. Bull. 100, 765-788.

Schaefer, K.M., Fuller, D.W., 2006. Estimates of age and growth of bigeye tuna (Thunnus obesus) in the eastern Pacific Ocean, based on otolith increments and tagging data. Inter-Am. Trop. Tuna Comm. Bull. 23, 32-76.

Schaefer, K.M., Fuller, D.W., 2009. Horizontal movements of bigeye tuna (Thunnus obesus) in the eastern Pacific Ocean, as determined from conventional and archival tagging experiments initiated during 2000-2005. Inter-Am. Trop. Tuna Comm. Bull. 24, 191-247.

Schaefer, K.M., Fuller, D.W., 2010. Vertical movements, behavior, and habitat of bigeye tuna (Thunnus obesus) in the equatorial eastern Pacific Ocean, ascertained from archival tag data. Mar. Biol. 157, 2625-2642.
Schaefer, K.M., Fuller, D.W., Miyabe, N., 2005. Reproductive biology of bigeye tuna (Thunnus obesus) in the eastern and central Pacific Ocean. Inter-Am. Trop. Tuna Comm. Bull. 23, 1-31.

Schaefer, K.M., Fuller, D.W., Block, B.A., 2011. Movements, behavior, and habitat utilization of yellowfin tuna (Thunnus albacares) in the Pacific Ocean off Baja California, Mexico, determined from archival tag data analyses, including Kalman filtering. Fish. Res. 112, 22-37.

Teo, S.L.H., Boustany, A., Blackwell, S., Walli, A., Weng, K.C., Block, B.A., 2004. Validation of geolocation estimates based on light level and sea surface temperature from electronic tags. Mar. Ecol. Prog. Ser. 283, 81-98.

Tomczak, M., Godfrey, J.S., 2003. Regional Oceanography: an introduction. Daya Books.

Tont, S.A., 1976. Deep scattering layers: patterns in the Pacific. Rep. Calif. Coop. Ocean. Fish. Invest. 18, 112-117.

Walker, M.M., 1984. Learned magnetic field discrimination in yellowfin tuna Thunnus albacares. J. Comp. Physiol. A 155, 673-679.

Williams, P., Terawasi, P., 2013. Overview of Tuna Fisheries in the Western and Central Pacific Ocean, Including Economic Conditions-2012. Western and Central Pacific Fisheries Commission, Document Number WCPFC-SC92013/GN WP-1, 56 pp. https://wcpfc.int/system/files/GN-WP-01-overviewtuna-fisheries-WCPO-inc-economics.pdf

Zar, J.H., 1974. Biostatistical Analysis. Prentice Hall, New Jersey. 